\title{
Regional radiative impact of volcanic aerosol from the 2009 eruption of Mt. Redoubt
}

\author{
C. L. Young, I. N. Sokolik, and J. Dufek \\ School of Earth and Atmospheric Sciences, Georgia Institute of Technology, Atlanta, Georgia \\ Correspondence to: I. N. Sokolik (isokolik@eas.gatech.edu) \\ Received: 9 August 2011 - Published in Atmos. Chem. Phys. Discuss.: 27 September 2011 \\ Revised: 24 February 2012 - Accepted: 26 March 2012 - Published: 24 April 2012
}

\begin{abstract}
High northern latitude eruptions have the potential to release volcanic aerosol into the Arctic environment, perturbing the Arctic's climate system. We present assessments of shortwave (SW), longwave (LW) and net direct aerosol radiative forcing efficiencies and atmospheric heating/cooling rates caused by volcanic aerosol from the 2009 eruption of Mt. Redoubt by performing radiative transfer modeling constrained by NASA A-Train satellite data. The optical properties of volcanic aerosol were calculated by introducing a compositionally resolved microphysical model developed for both ash and sulfates. Two compositions of volcanic aerosol were considered in order to examine a fresh, ash rich plume and an older, ash poor plume. Optical models were incorporated into a modified version of the SBDART radiative transfer model. Our results indicate that environmental conditions, such as surface albedo and solar zenith angle (SZA), can influence the sign and the magnitude of the radiative forcing at the top of the atmosphere (TOA) and at the surface and the magnitude of the forcing in the aerosol layer. We find that a fresh, thin plume $(\sim 2.5-7 \mathrm{~km})$ at an AOD $(550 \mathrm{~nm})$ range of $0.18-0.58$ and $\mathrm{SZA}=55^{\circ}$ over snow cools the surface and warms the TOA, but the opposite effect is seen for TOA by the same layer over ocean. The layer over snow also warms by $64 \mathrm{~W} \mathrm{~m}^{-2} \mathrm{AOD}^{-1}$ more than the same plume over seawater. The layer over snow at $\mathrm{SZA}=75^{\circ}$ warms the TOA $96 \mathrm{~W} \mathrm{~m}^{-2} \mathrm{AOD}^{-1}$ less than it would at $\mathrm{SZA}=55^{\circ}$ over snow, and there is instead warming at the surface. We also find that plume aging can alter the magnitude of the radiative forcing. An aged plume over snow at $\mathrm{SZA}=55^{\circ}$ would warm the TOA and layer by 146 and $143 \mathrm{~W} \mathrm{~m}^{-2} \mathrm{AOD}^{-1}$ less than the fresh plume, while the aging plume cools the surface $3 \mathrm{~W} \mathrm{~m}^{-2} \mathrm{AOD}^{-1}$ more. Comparing results for the thin plume to those for a thick plume $(\sim 3-20 \mathrm{~km})$, we find that
\end{abstract}

the fresh, thick plume with $\operatorname{AOD}(550 \mathrm{~nm})=3$, over seawater, and $\mathrm{SZA}=55^{\circ}$ heats the upper part of the plume in the $\mathrm{SW} \sim 28 \mathrm{~K} \mathrm{day}^{-1}$ more and cools in the $\mathrm{LW}$ by $\sim 6.3 \mathrm{~K} \mathrm{day}^{-1}$ more than a fresh, thin plume under the same environmental conditions. We compare our assessments with those reported for other aerosols typical to the Arctic environment (smoke from wildfires, Arctic haze, and dust) to demonstrate the importance of volcanic aerosols.

\section{Introduction}

Mt. Redoubt is a stratovolcano located in Alaska, USA. Rising to an elevation of $3108 \mathrm{~m}$ (10 $197 \mathrm{ft})$, Redoubt is the second tallest volcano in the Aleutian Range. Redoubt has been active five times since 1900, with the most recent eruptions occurring in 1989 and 2009. The last period of explosive eruptions began on 23 March 2009 and lasted through 4 April 2009. Eruptive plumes reached into the stratosphere on several occasions, reduced air quality and posed a threat to aviation (Carlile and Nelson, 2009; M. Coombs and J. Schaefer, personal communication, 2011). However, little attention has been given to the regional radiative impact of volcanic aerosols. Here, we use the 2009 eruption of Redoubt as an opportunity to assess a range of the radiative impacts that may be expected from high northern latitude eruptions.

The primary mechanism by which volcanic eruptions alter the Earth's climate is through the formation of sulfate aerosols. Sulfates may persist in the stratosphere for up to three years (Clarisse et al., 2008), causing the stratosphere to warm and the surface to cool (Robock, 2000). Ash expelled by volcanic eruptions can also interact with electromagnetic radiation, but the lifetime of fine ash in the stratosphere is 
only on the order of a few weeks (Niemeier et al., 2009). It is for this reason sulfates are the principal aerosol commonly used to predict the global climate perturbation expected from a given eruption (Stenchikov et al., 1998; Ramachandran et al., 2000). However, on regional scales, both volcanic ash and sulfate aerosols in the troposphere become important. In this case, sulfates and ash have similar residence times, on the order of days to weeks. Therefore, ash particles must be considered along with sulfate aerosol in estimating the regional radiative impact, as well as specific environmental conditions including surface albedo, solar zenith angle (SZA), regional weather, and other aerosol types present in the region.

Volcanic aerosols may be expected to have a particularly strong influence on the regional Arctic climate because of the high sensitivity of the Arctic environment to radiative perturbations, as indicated by numerous studies focusing on other aerosol types, both natural (Myhre et al., 2007; Stone et al., 2007, 2008) and anthropogenic (Ritter et al., 2005; Quinn et al., 2007, 2008). The resulting forcing aerosols will have on the Arctic environment is strongly controlled by the seasonality of many related factors, such as the amount of incoming solar radiation, surface albedo, precipitation, and transport of pollutants (Quinn et al., 2008; Sokolik et al., 2011). There is a large increase in tropospheric aerosols in the Arctic in late winter and early spring each year, which leads to the creation of Arctic haze (Quinn et al., 2008). The hazeproducing emissions are largely from Europe and Asia and consist of sulfate and nitrate aerosols, organic carbon, and soot (Klonecki et al., 2003; Stohl, 2006; Quinn et al., 2008). The importance of surface albedo has been investigated, and in general, an absorbing aerosol (i.e., smoke) over a highly reflective surface tends to reduce the amount of solar energy reaching the surface, while leading to warming in the aerosol layer (Stone et al., 2008; Shaw and Stamnes, 1980). Given the high surface albedos common during Arctic springtime, even aerosols with a moderate absorbing capability can have this effect (Quinn et al., 2008). However, the effects of natural aerosols, such as volcanic aerosol, were not considered by Quinn et al. (2008) in making recommendations to mitigate Arctic warming due to anthropogenic aerosols.

The impact of volcanic aerosols on the Arctic climate is difficult to assess because of their complex nature and limited measurements of physical and chemical properties. Additional complexity comes from seasonal variations that dramatically alter the amount of incoming solar radiation and surface reflectivity. Additionally, volcanic aerosol may have an indirect effect on clouds (Lohmann et al., 2003; Sokolik et al., 2011). It is also possible that ash deposits may lower the albedo of ice and snow covered surfaces, which would be expected to perturb the Arctic's radiation budget just as soot deposits (Flanner et al., 2007) and dust deposits (Painter et al., 2010) have been shown to do.

Performing optical and radiative transfer calculations requires information on aerosol composition, size distribu- tions, and types of aerosol present. Composition must be known in order to determine the spectral refractive index. Satellite data has been employed to determine size distributions of sulfates after eruptions (Stenchikov et al., 1998; Ramachandran et al., 2000). Particle counter measurements on balloons and aircraft have aided in calculating size distributions of stratospheric sulfuric acid aerosol (Jager and Deshler, 2002; Deshler et al., 1992, 1993; Deshler, 2008; Pueschel et al., 1994); however, these measurements have typically been made several weeks to months after the eruption, which does not help to determine the size distributions of "fresh" volcanic sulfate or ash. Therefore, in efforts to study the formation and aging process of volcanic sulfates, models have been developed to calculate how the size distribution evolves (Stier et al., 2005) and have been incorporated into general circulation models (Niemeier et al., 2009). For volcanic ash, there have been few airborne measurements of size distribution, mainly due to the dangers involved in making this measurement. Although size distributions have been measured on ashfall samples (Munoz et al., 2004; Martin et al., 2009; Riley et al., 2003; Scott and McGimsey, 1994), these values will not be representative of the actual size distribution during an eruption due to sorting which occurs during transport in the atmosphere (Rose and Durant, 2009). As the volcanic plume ages, the radiative properties of the plume are significantly altered by the changing size and composition of volcanic aerosols. Thus, it is important to examine how the aging of volcanic aerosol affects the radiative impact.

The goal of this study is to assess the range of regional radiative impact of volcanic aerosol from the 2009 eruption of Mt. Redoubt using satellite data and a radiative transfer model. We examine both the longwave (LW) and shortwave (SW) components of the direct radiative forcing at the top of the atmosphere (TOA) and at the surface, and SW and LW atmospheric heating/cooling rates. This work employs a satellite multiple sensor approach to constrain the transport, areal and vertical extent, and characteristics of volcanic plumes. The organization of the paper is as follows. Section 2 presents the data used in this study and introduces a methodology to create a compositionally resolved microphysical model for volcanic aerosols. The size distributions and refractive indices selected for optical calculations are discussed, as well as the satellite data products utilized in the radiative transfer model. Section 3 discusses results of direct aerosol radiative forcing efficiencies (DARFEs) and atmospheric heating/cooling rate profiles in terms of sensitivity to plume-specific and environmental input parameters for the Arctic region. Section 4 summarizes the important findings of this study and makes recommendations for future research. 
Table 1. Input parameters for SBDART. Sulfate size distribution was held constant at an effective radius of $0.5 \mu \mathrm{m}$ and $\sigma$ of 0.5 (Kearney and Watson, 2009). For ash, $\sigma$ is set to 0.59 and held constant for all simulations (Niemeier et al., 2009). Refractive indices for sulfate from OPAC were used for $70 \%$ sulfate solution. For ash, refractive indices of andesite from Pollack et al. (1973) were used.

\begin{tabular}{lll}
\hline Model Parameter & Input & Source of input \\
\hline Vertical placement and physical & 2.5 to $7 \mathrm{~km}^{\mathrm{a}}$ & CALIPSO $^{\mathrm{a}}$ \\
thickness of the aerosol layer & 3 to $20 \mathrm{~km}^{\mathrm{b}}$ & AVO estimate based on radar $b$ \\
Aerosol Optical Depth & $0.18,0.38,0.58^{\mathrm{a}}$ & MODIS $\mathrm{b}$ \\
& $1,2,3^{\mathrm{b}}$ & \\
& Seawater $(0.041$ at $550 \mathrm{~nm})$ & SBDART \\
& Snow $(0.973$ at $550 \mathrm{~nm})$ & \\
Solar zenith angle & $55^{\circ}-75^{\circ}$ & Realistic sun angles \\
Range of ash to sulfate ratio & $9: 1$ to $1: 9$ & MODIS fine mode fraction \\
$R_{\text {eff }}$ of ash & $1.5-5 \mu \mathrm{m}$ & Spinetti et al. (2008)
\end{tabular}

a indicates values used for the 2 April case study. ${ }^{b}$ indicates values used in sensitivity study. For both plumes, aerosol optical depth was distributed uniformly within the layer.

\section{Data and methodology}

Our approach uses satellite data in conjunction with the HYSPLIT transport model for volcanic ash to constrain a radiative transfer model. The HYSPLIT computes the dispersion and transport of an evenly distributed vertical column of ash with a given size distribution placed directly over the volcano summit (Draxler and Rolph, 2011; Rolph, 2011). The following parameters are needed to run the model: volcano latitude and longitude, volcano summit height, eruption date and time, eruption duration, and ash column height. In this study the HYSPLIT model was run for selected eruptions in order to provide supporting evidence that the aerosol plumes detected by satellites are indeed volcanic in origin.

\subsection{Satellite data}

The NASA A-Train satellite constellation provides the unique capability of passive and active collocated satellite sensors to study volcanic eruptions (Carn et al., 2009; Thomas et al., 2009). The CALIOP lidar flies aboard the CALIPSO (Cloud-Aerosol Lidar and Infrared Pathfinder Satellite Observations) platform and measures backscatter at 532 and $1064 \mathrm{~nm}$. Past studies have successfully employed CALIPSO to investigate the vertical structure of volcanic plumes (Thomason and Pitts, 2008; Yuan et al., 2011). Vertical profiles are useful in determining the position of the plume within the atmosphere, as well as plume top heights and thicknesses. Vertical profiles of aerosol were obtained from CALIPSO version 3.01 data. The sensors OMI and MODIS have greater spatial coverage and were used both to identify and track the plumes and to validate some of the products retrieved from CALIPSO.

The OMI instrument on the Aura spacecraft has an ultraviolet - visible spectral range of $0.27-0.50 \mu \mathrm{m}$ and provides the UV aerosol index (AI) (Torres et al., 2007). The AI is a semi-quantitative indicator of the presence of UV-absorbing aerosols, such as volcanic ash, smoke, and dust. It is im- portant to note that sulfate aerosols do not absorb UV radiation and will have negative values of $\mathrm{AI}$, in contrast to UV-absorbing aerosols which have positive AI values.

The MODIS sensor flies on both the Terra and Aqua satellites. In this study, we employed true color MODIS images, aerosol optical depth (AOD) at $550 \mathrm{~nm}$, and aerosol fine mode fraction products. The MODIS level 3 Collection 5 AODs were used to constrain the areal extent of volcanic plumes and determine a range of AODs for calculation of the radiative forcing. Fine mode fraction is the ratio of small mode optical depth to the total AOD (Remer et al., 2005). We used MODIS level 2 Collection 5 fine mode fraction to determine approximate proportions of fine and coarse particles present in a plume.

\subsection{Aerosol microphysical model}

The optical properties of volcanic aerosol were determined through the development of a compositionally resolved microphysical model. In general, volcanic aerosols may be composed of ash, sulfates, hydrometeors, and ash particles coated with sulfates, water, and/or ice (Rose et al., 2004; Prata et al., 2007; Textor et al., 2006; Pueschel et al., 1994). Here, we considered only ash and sulfate, both of which have distinct size distributions and spectral refractive indices. We incorporated representative size distributions and refractive indices for ash and sulfate using data reported in the literature, as well as a range of realistic ratios of fine to coarse modes and ash to sulfate deduced from satellite data (Kearney and Watson, 2009; Niemeier et al., 2009; Pollack et al., 1973; Spinetti et al., 2008; Stenchikov et al., 1998). A summary of the considered cases is presented in Table 1.

We used lognormal particle size distributions for both ash and sulfate in the following form (Kearney and Watson, 2009):

$n_{c}(r)=\frac{1}{\sqrt{2 \pi} \sigma} e^{-\frac{(\ln (r)-\mu)^{2}}{2 \sigma^{2}}}$ 
where $n_{c}$ is the particle number concentration, $r$ is the particle radius, and $\sigma$ is the variance of the size distribution, or the log of the standard deviation:

$\mu=\left(\ln R_{\mathrm{eff}}\right)-2.5 \sigma^{2}$,

where $R_{\text {eff }}$ is the effective radius.

We assume that sulfate occurs only in the fine mode, but ash can exist in both coarse and fine modes. To simulate fresh sulfate aerosol in a young volcanic plume, an effective radius of $0.5 \mu \mathrm{m}$ and $\sigma$ of 0.5 were used (Kearney and Watson, 2009). The size distribution of sulfate was held constant in order to study the effects of ash fallout. For ash, $\sigma$ was set to 0.59 and held constant for all simulations, as in Niemeier et al. (2009). Effective radius for ash was allowed to vary from $5 \mu \mathrm{m}$ to $1.5 \mu \mathrm{m}$, according to satellite retrievals of effective radii of ash in an aging plume reported by Spinetti et al. (2008). It should be noted that these previous studies do not include a truly " fine" ash portion (aerodynamic diameter $<2.5 \mu \mathrm{m}$ ), and therefore we only considered ash in the coarse mode.

Refractive indices for both SW $(0.3-4 \mu \mathrm{m})$ and LW (4$20 \mu \mathrm{m})$ spectral regions for ash and sulfate were taken from the literature. The OPAC data were used for $70 \%$ sulfuric acid solution (Hess et al., 1998) to represent sulfate aerosol. For ash, refractive indices of andesite from Pollack et al. (1973) were used. Sulfuric acid solutions around $70 \%$ are commonly chosen for radiative transfer modeling of volcanic aerosol and are valid for most situations (e.g., Stenchikov et al., 1998). However, measurements of temperature and relative humidity in the Arctic suggest that the sulfuric acid solution can be as low as 40-50\% (Yue et al., 1994; Russell et al., 1996; Lambert et al., 1997). These measurements are based on temperature and relative humidity of ambient Arctic air. Temperatures and relative humidities in a fresh volcanic plume are much higher, as magmatic volatiles in arc volcanoes are water rich (Williams and McNutt, 2005). Therefore, we felt the $70 \%$ sulfuric acid solution was more realistic for a fresh volcanic plume than the lower values occurring in Arctic environments.

Ratios of fine and coarse mode aerosols were constrained with MODIS fine mode fraction retrievals. For the purposes of our study, the fine mode fraction represents the particle number proportion of sulfate present in an externally mixed aerosol mixture containing ash and sulfate. In order to realistically bracket the range of radiative forcing associated with ash fallout as a plume ages, an ash rich mixture (containing smaller fractions of sulfate and larger proportions of ash) was used as a proxy for a fresh plume, and a sulfate rich mixture (consisting of higher proportions of sulfate and a smaller ash fraction) was chosen to simulate a more evolved, aged plume.

\subsection{Radiation transfer calculations}

The 1-D radiative transfer model used in this study is a modified version of the Santa Barbara Disort Atmospheric Ra- diative Transfer (SBDART) model. SBDART solves the radiative transfer equation using the Discrete Ordinate Radiative Transfer (DISORT) method for a plane parallel atmosphere (Ricchiazzi et al., 1998). The online version of SBDART is available at http://paulschou.com/tools/sbdart/. The model takes into account gaseous absorption and absorption and multiple scattering by aerosols. The model was modified to incorporate a user defined aerosol layer and the aerosol optical characteristics computed in this study. A spectral resolution of $5 \mathrm{~nm}$ for the $\mathrm{SW}$ and $20 \mathrm{~cm}^{-1}$ for the LW was used in modeling the upward and downward radiative fluxes. The subarctic winter standard atmospheric model (McClatchey et al., 1972) was used in radiative transfer calculations over seawater and snow surfaces with solar zenith angle (SZA) ranging from $55^{\circ}$ to $75^{\circ}$. The spectral surface albedo for water and snow are from Viollier (1980) and Wiscombe et al. (1980), respectively.

Net fluxes for both the SW and LW components at the topof-the-atmosphere (TOA) and at the surface were computed by subtracting the upward flux from the downward flux:

$F_{\text {net }}=F_{\text {down }}-F_{\text {up }}$

The total net flux at TOA and at the surface were then calculated by adding the respective SW and LW net fluxes

$F_{\text {net total }}=F_{\text {net, } \mathrm{SW}}+F_{\text {net, } \mathrm{LW}}$

Atmospheric heating rates in units of $\mathrm{Kday}^{-1}$ were calculated as follows:

$\frac{d T}{d t}=-\frac{1}{c_{p}} \rho \frac{d F_{\text {net }}}{d z}$

where $c_{p}$ is the specific heat at constant pressure $\left(c_{p}=\right.$ $1004.67 \mathrm{~J} \mathrm{~kg}^{-1} K^{-1}$ ), and $\rho$ is the air density of the aerosol layer. The change in net flux with respect to altitude is represented by $d F_{\text {net }} / d z$. We also computed and analyzed the direct aerosol radiative forcing, DARF, and direct aerosol radiative forcing efficiency, DARFE. The latter is defined as the change in the net flux with respect to the change in AOD $(550 \mathrm{~nm})$ :

$\mathrm{DARFE}=\Delta F_{\text {net }} / \Delta \mathrm{AOD}(550 \mathrm{~nm})$

To calculate DARFE for an aerosol layer, the surface DARFE was subtracted from the DARFE at TOA

$\mathrm{DARFE}_{\mathrm{atm}}=\mathrm{DARFE}_{\mathrm{TOA}}-\mathrm{DARFE}_{\text {surface }}$

For each study case, we computed DARFE $_{\mathrm{TOA}}$, DARFE $_{\text {surface, }}$ and DARFE $_{a t m}$ for $\mathrm{SW}$, LW, and net forcing. The units of DARF are $\mathrm{W} \mathrm{m}^{-2}$ and DARFE are $\mathrm{W} \mathrm{m}^{-2} \mathrm{AOD}^{-1}$. The definition of DARFE used in our study is similar to that of Stone et al. (2008) to facilitate the comparison with results for other aerosol types. 


\section{Results and discussion}

\subsection{Optical properties of volcanic aerosol}

Based on satellite data analyses (see Sect. 3.2), two externally mixed aerosol mixtures with varying proportions of ash and sulfate were selected to simulate plume aging. The refractive indices for sulfate and andesite are shown in Fig. 1a. The normalized extinction coefficients, $K_{e}$, for the two aerosol mixtures and their sulfate and andesite constituents are shown in Fig. $1 \mathrm{~b}$ as a function of wavelength. The normalized extinction coefficient is a measure of scattered and absorbed radiation by particles per unit concentration. Andesite absorbs and scatters both SW and LW radiation. The ash rich mixture is dominated by andesite ash. Sulfate scatters SW radiation and absorbs LW radiation, with negligible scattering in the LW because of small particle size. It is clear from Fig. $1 \mathrm{~b}$ that the ash rich mixture resembles that of pure andesite, and the sulfate rich mixture more closely resembles that of sulfate. It is also apparent from Fig. 1b that the extinction coefficient per unit concentration is larger for both pure andesite and the ash dominated mixture at all wavelengths.

Figure 1c shows the single scattering albedo, $\omega_{0}$, for both aerosol compositions. The single scattering albedo is the fraction of photons that would be scattered by aerosols. In the SW, the ash rich mixture absorbs light more effectively than the sulfate rich one until about $2.5 \mu \mathrm{m}$. At longer wavelengths, the ash rich mixture scatters radiation better than the sulfate dominated composition.

\subsection{Satellite data analysis to constrain a radiative transfer model}

The study cases presented here were selected by performing an integrated analysis of satellite data for the entire period of explosive volcano activity between 22 March and 4 April. For each day in this time frame, CALIPSO overpasses were analyzed for a boxed region located $43^{\circ} \mathrm{N}$ to $69^{\circ} \mathrm{N}$ and $130^{\circ} \mathrm{W}$ to $160^{\circ} \mathrm{W}$. A large collection region was needed to obtain a sufficient amount of data, because of CALIPSO's narrow swath. Therefore, it was expected if CALIPSO were to detect a plume, it would be after transport had carried it some distance from the source. Only data that showed clear detection of an aerosol plume with well-developed vertical structure in CALIPSO's vertical cloud feature mask were selected. Aerosol index and $\mathrm{SO}_{2}$ measurements from $\mathrm{OMI}$ and AOD from MODIS were then used to determine the likely source region of the detected aerosol plume and to provide evidence that it was volcanic in origin.

The 17:24 UTC eruption on 26 March and the 13:58 and 14:16 UTC eruptions on 4 April were among the most violent eruptions, spewing ash well into the stratosphere (Carlile and Nelson, 2009; M. Coombs and J. Schaefer, personal communication, 2011). MODIS (Fig. 2) and OMI AI (Fig. 3) help
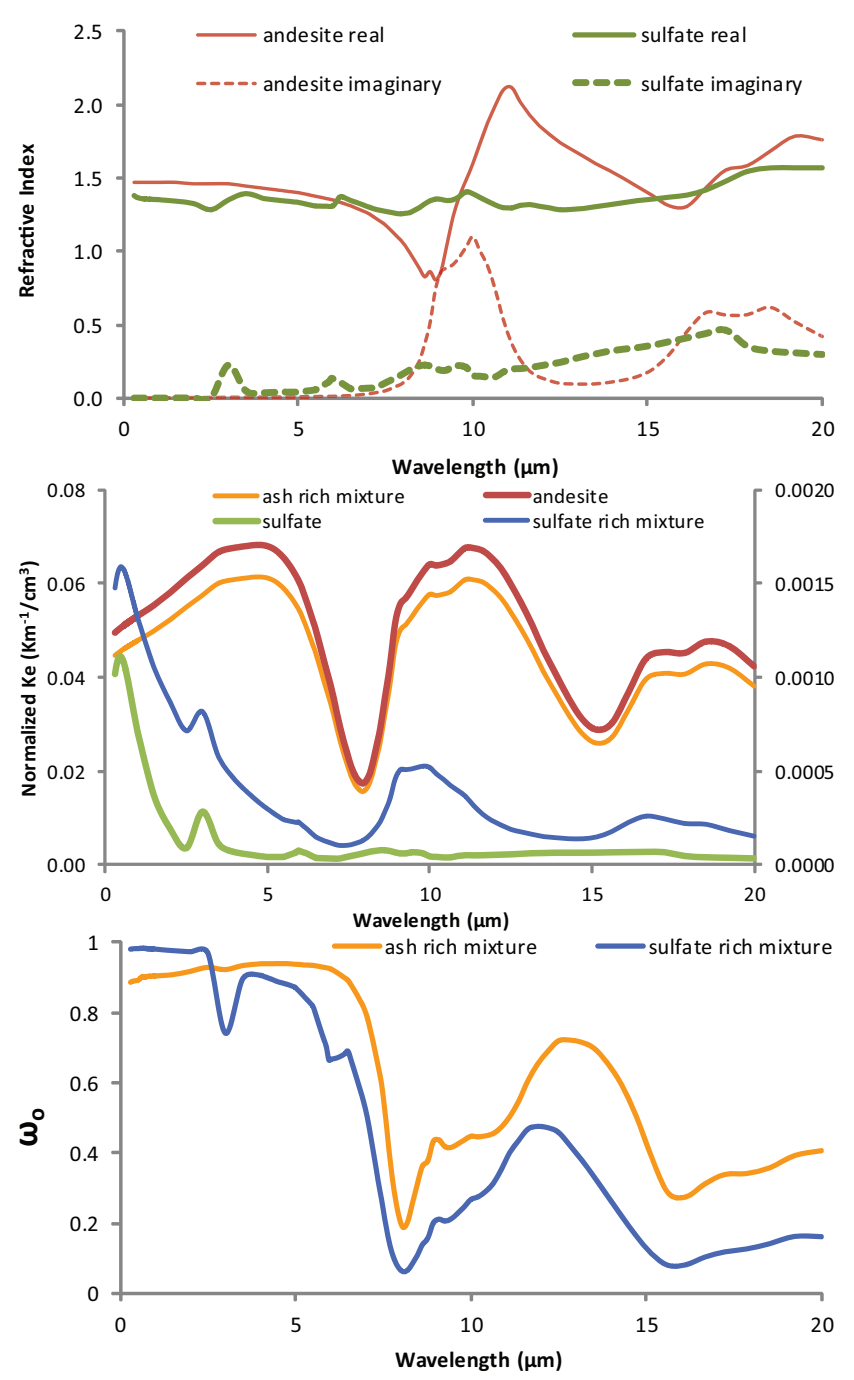

Fig. 1. (a) Spectral dependence of refractive indices of ash and sulfate. (b) Concentration normalized extinction coefficients $\left(K_{\mathrm{e}}\right)$ versus wavelength for an ash rich mixture containing an ash to sulfate ratio of 9 to 1 and an effective radius for ash $R_{\text {eff }}=5 \mu \mathrm{m}$ compared to andesite with $R_{\text {eff }}=5 \mu \mathrm{m}$ (right axis) and for a sulfate rich mixture containing an ash to sulfate ratio of 1 to 9 and an effective radius for ash $R_{\text {eff }}=1.5 \mu \mathrm{m}$ compared to sulfate with $R_{\text {eff }}=0.5 \mu \mathrm{m}$ (left axis). (c) Single scattering albedo $\left(\omega_{0}\right)$ versus wavelength for an ash rich mixture containing an ash to sulfate ratio of 9 to 1 and $R_{\text {eff }}=5 \mu \mathrm{m}$ and a sulfate rich mixture containing an ash to sulfate ratio of 1 to 9 and $R_{\text {eff }}=1.5 \mu \mathrm{m}$.

confirm the presence of ash in these plumes, as well as provide insight into the overall transport of aerosol. The plume detected on 4 April (Fig. 2b and 3b) appears to be moving southeast of the volcano, over the Gulf of Alaska. However, the plume from 26 March (Fig. 2a and 3a) appears to be transporting ash both north of the volcano over Alaska, and southeast of the volcano. The transport of plumes on 26 March and 4 April over both seawater and snow surfaces 


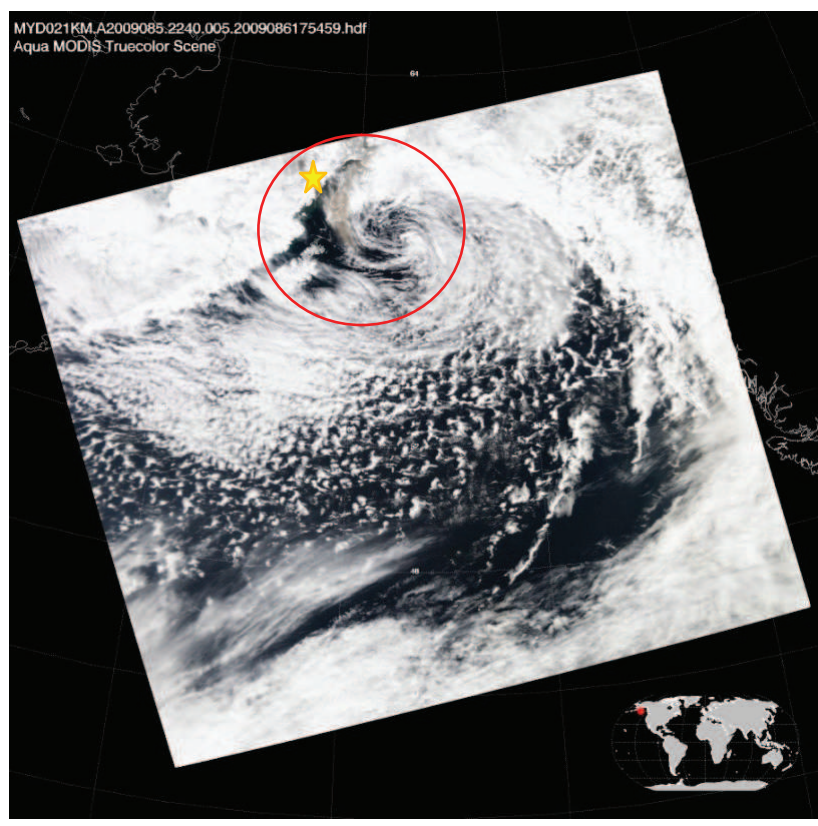

(a)

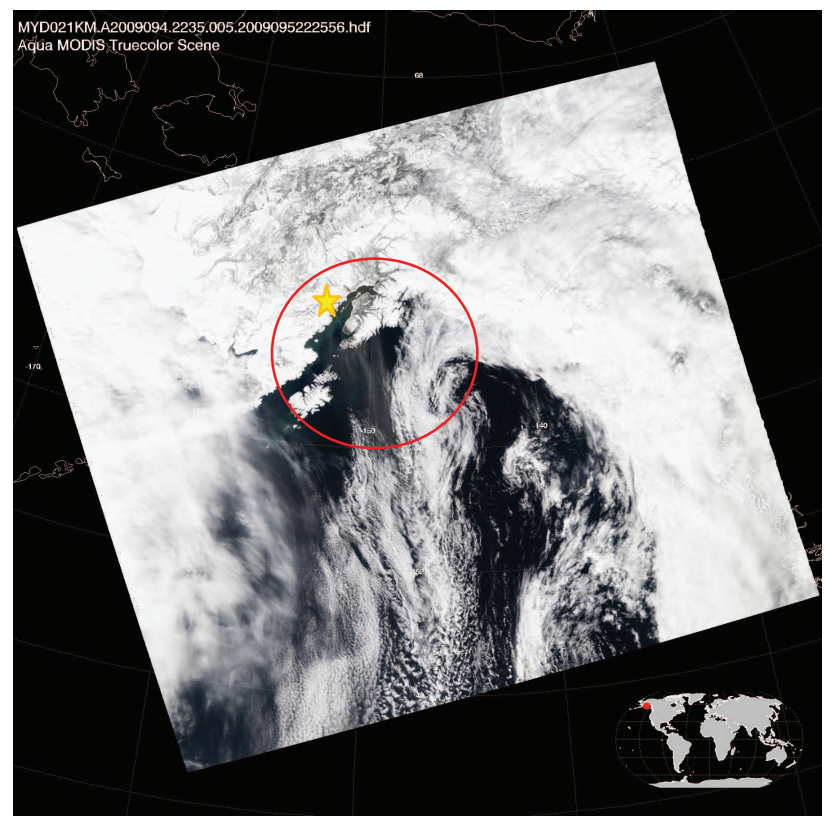

(b)

Fig. 2. Aqua MODIS true color images on (a) 26 March at 22:40 UTC and (b) 4 April at 22:35 UTC. The aerosol plume is circled in red. The location of Mt. Redoubt is marked by a star.

illustrates the need for assessing the radiative forcing for different surface albedos.

However, CALIPSO data on 26 March and 4 April is not available due to the extensive cloud cover present during much of March and early April. After examining satellite data for the entire span of the explosive eruptions within the domain chosen, it was determined that the best data avail-
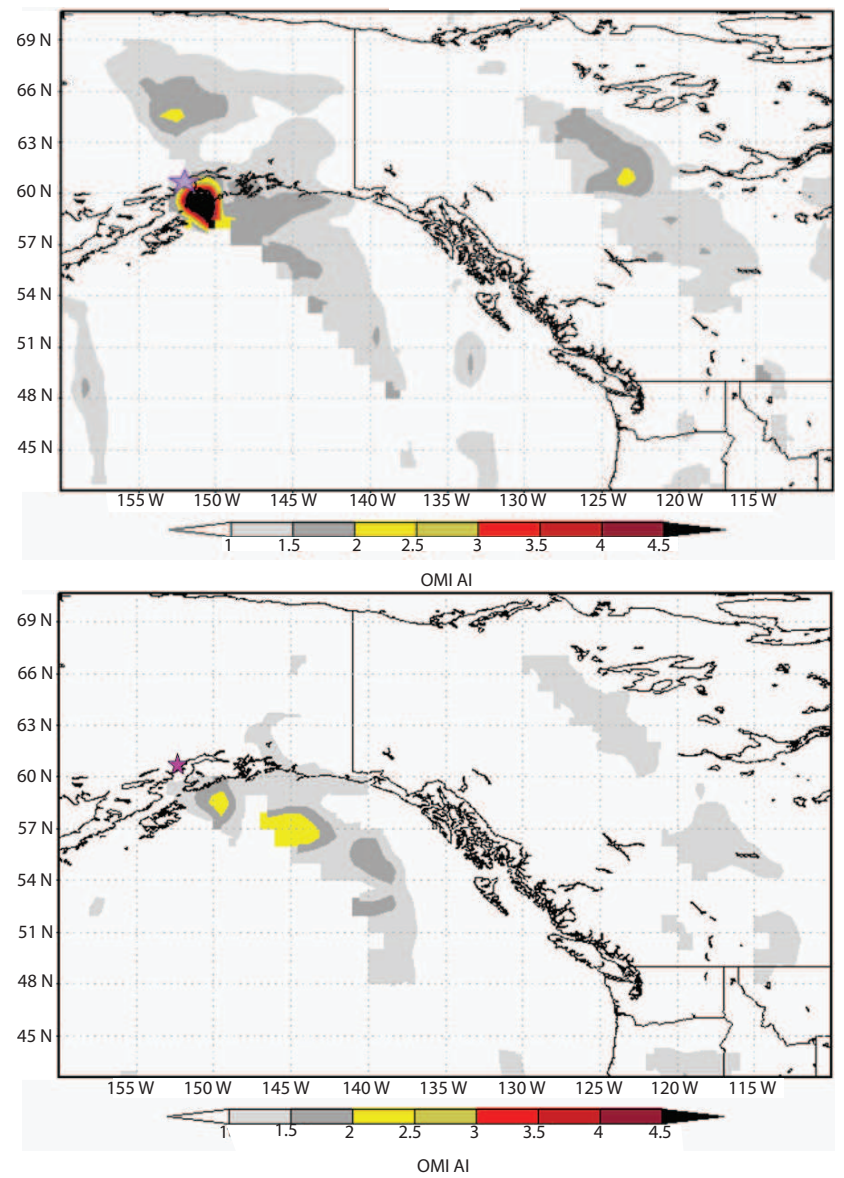

Fig. 3. OMI AI for (a) 26 March and (b) 4 April. The location of Mt. Redoubt is marked by a star.

able were obtained for a plume detected on 2 April. The aerosol profiles from CALIPSO reveal that the plume is completely contained in the troposphere and extends from $\sim 2.5-7 \mathrm{~km}$ (Fig. 4a). The plume thickness obtained from CALIPSO (Fig. 4a), together with total column AODs from MODIS, which range from 0.18 to 0.58 (Fig. 4b), suggest that this plume is moderately thin. Out of 22 CALIPSO overpasses in the selected domain, only the aerosol profile detected on 2 April clearly displays a well-defined vertical volcanic aerosol structure (Fig. 4a). In the absence of true color images on this day, the other sensors employed in this study, along with HYSPLIT, can confirm the volcanic origin of aerosol detected by CALIPSO. Both MODIS (Fig. 4b) and OMI (Fig. 4c) were able to detect volcanic aerosol, which appears to be traveling southeast of the volcano. On 2 April, there were intermittent low level emissions throughout the day, according to plume heights compiled by the Alaska Volcano Observatory (AVO) from ground based radar estimates (Carlile and Nelson, 2009). The HYSPLIT model predicts that ash from a low level eruption travels to the southeast of the volcano (Fig. 4d). Combined evidence from MODIS, OMI, and HYSPLIT confirms that 


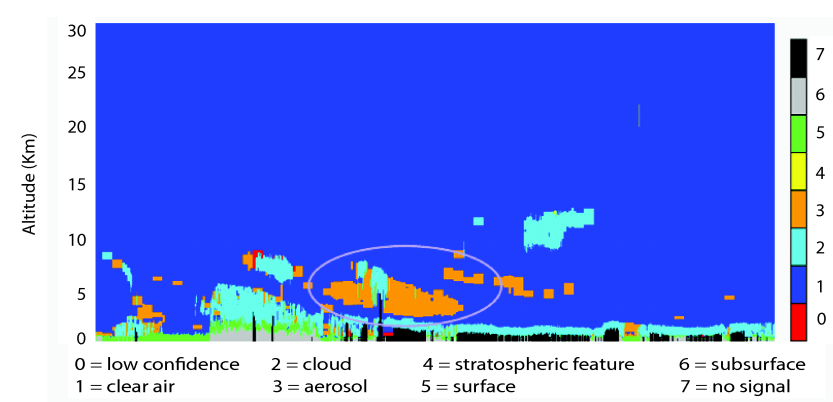

(a)

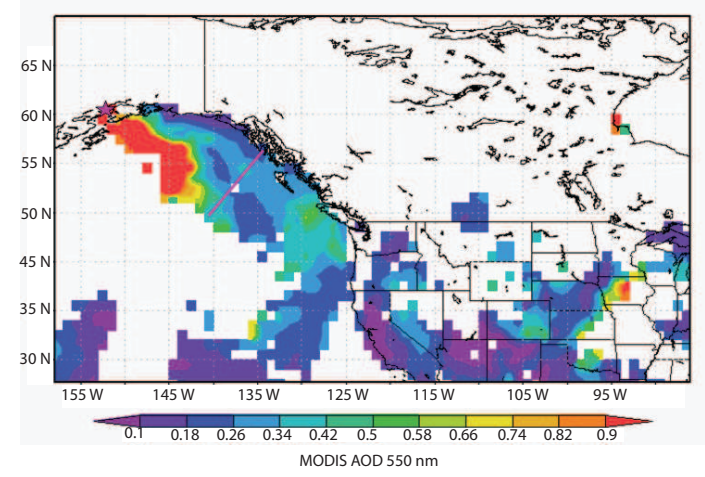

(b)

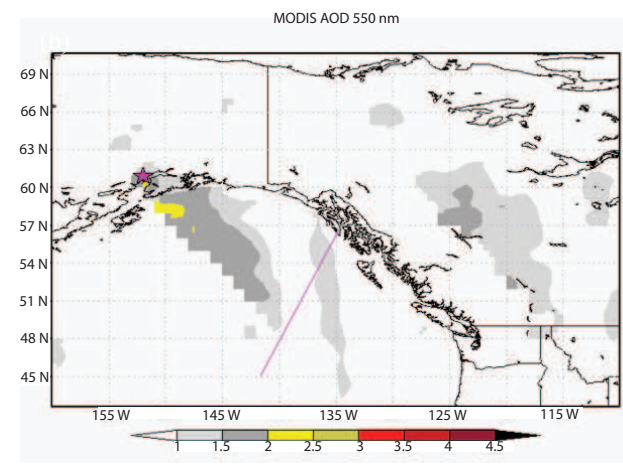

OMIAI

(c)

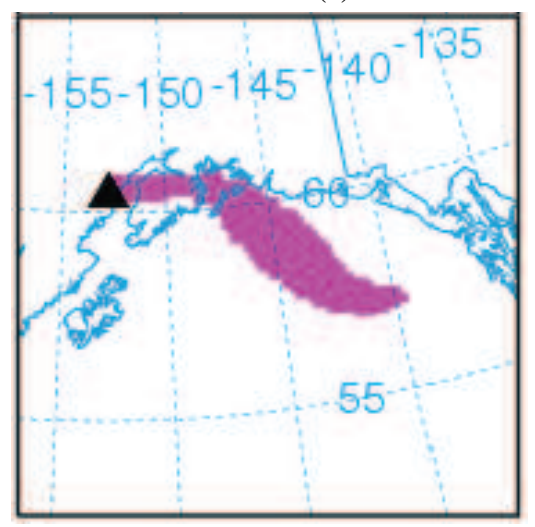

(d)

Fig. 4. (a) Vertical feature mask from CALIPSO between 11:31 UTC and 11:45 UTC on 2 April. The plume of interest is circled. (b) MODIS AOD $(550 \mathrm{~nm})$ daily mean for 2 April. Mt. Redoubt is marked with a star. CALIPSO path is shown with a line. (c) Same as (b), except for OMI AI. (d) Transport of ash plume (shown in pink) from the 2 April eruption as predicted by the HYSPLIT model. Eruption duration of 12 hours and an ash column height of $4.6 \mathrm{~km}$ were used.

the aerosol plume detected by CALIPSO is dominated by volcanic aerosols and that it has been carried away from its source.

For Mie calculations to determine optical properties of aerosol, it is essential to know if both ash and sulfate are present and proportions of ash to sulfate. Nonsphericity was detected in the 2 April plume using particle depolarization ratios from CALIPSO. Fragmented ash particles are expected to register nonspherical. The OMI AI image (Fig. 4c) also supports the presence of UV-absorbing aerosol, such as volcanic ash. The presence of ash or sulfate cannot be determined by MODIS AOD $(550 \mathrm{~nm})$, because it detects both types of volcanic aerosol. However, proportions of fine and coarse mode aerosol can be constrained by MODIS fine mode fraction (Fig. 5). In order to conservatively bracket the range of radiative forcing possible from this eruption, two volcanic aerosol compositions are considered, based on the highest and lowest values in the MODIS fine mode fraction (Fig. 5). The first composition was built to simulate a young, ash rich plume with an ash to sulfate ratio of 9 to 1 , while the other composition represents an older, ash poor plume having an ash to sulfate ratio of 1 to 9 .
However, the 2 April case study alone does not allow us to comprehensively assess the full range of radiative effects possible from this eruption. In order to better examine the role of vertical structure, we constructed a profile for a thick, optically opaque plume, forming directly over the volcano based on both the largest value of AOD and the maximum height for plumes detected throughout the course of the eruptions. The highest MODIS daily average AOD occurred on 27 March, and values of MODIS AOD chosen ranged from 1 to 3 (Fig. 6). The tallest plume height was produced by the 17:24 UTC eruption on 26 March, reaching $\sim 20 \mathrm{~km}$ (Carlile and Nelson, 2009; M. Coombs and J. Schaefer, personal communication, 2011). The same aerosol compositions introduced for the plume detected on 2 April were used in this vertical structure in order to simulate plume aging.

\subsection{The effect of volcanic aerosols on the Arctic radiation balance}

We first consider the 2 April case and then examine the extent of the radiative effects by introducing a plume with a different vertical structure that was described in Sect. 3.2. 


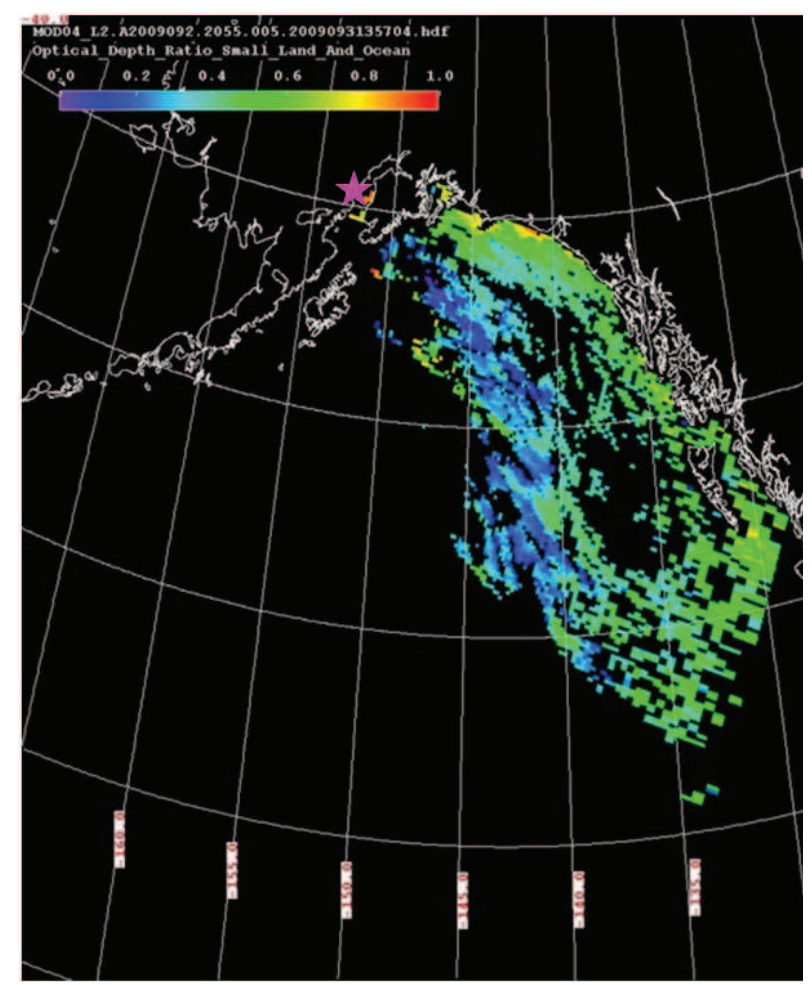

Fig. 5. Terra MODIS fine mode fraction AOD on 2 April at 20:55 UTC. Mt. Redoubt is marked by a star.

Radiative forcings and heating/cooling rates were computed for the two plumes as they age and for a range of SZAs and surface albedos. Comparisons between the two plume profiles aid in determining the sensitivity of the radiative impact to plume structure and aerosol loading. Model input is summarized in Table 1.

\subsubsection{Case study of volcanic plume detected on 2 April}

The plume detected on 2 April 2009 was an optically thin volcanic aerosol plume, stretching from 2.5 to $7 \mathrm{~km}$ in altitude and having total column AOD at $550 \mathrm{~nm}$ ranging from 0.18 to 0.58 . We use this case study to investigate the nature of volcanic aerosol and how plume aging and environmental parameters, such as surface albedo and SZA, influence the extent of the radiative impact. This is done for both $\mathrm{SW}$ and LW components. For a given set of environmental conditions, the effect of plume aging alone is to control the magnitudes of the radiative impact. Figure 7 displays the relationship between the net SW flux and $\operatorname{AOD}(550 \mathrm{~nm})$ at the surface and TOA at $\mathrm{SZA}=55^{\circ}$. Over both seawater and snow surfaces and for each AOD, the TOA net SW flux is greater for an ash rich plume than for a plume consisting primarily of sulfate (Fig. 7). As shown in Fig. 1, the reason for this is that the sulfate rich mixture scatters SW radiation more efficiently than does the volcanic aerosol enriched in ash. Conversely, over both types of surfaces for each measured AOD,

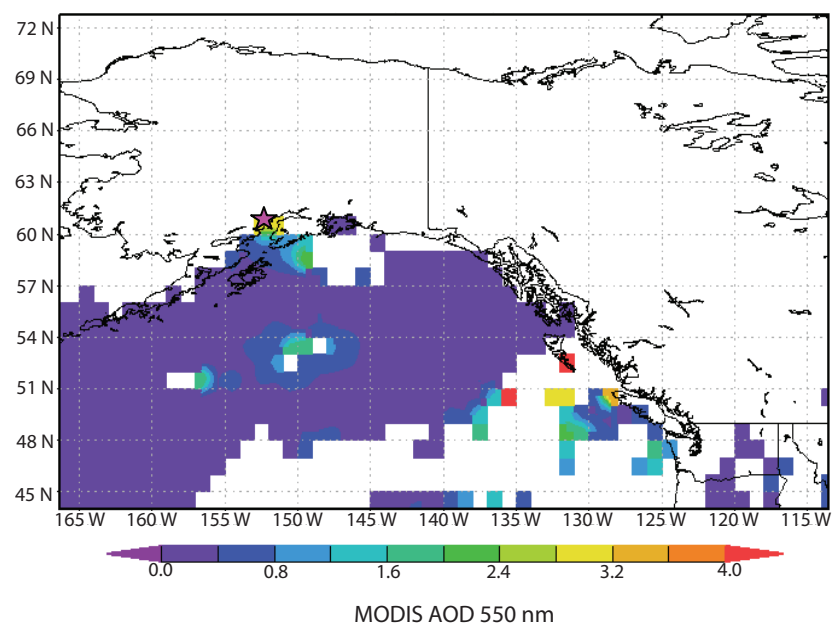

Fig. 6. MODIS AOD $(550 \mathrm{~nm})$ daily average for 27 March. These AOD values were the highest over the entire course of the explosive eruptions, due to aerosol produced by the very powerful eruption at 17:24 UTC on March 26 and the eruptions that followed on 27 March.

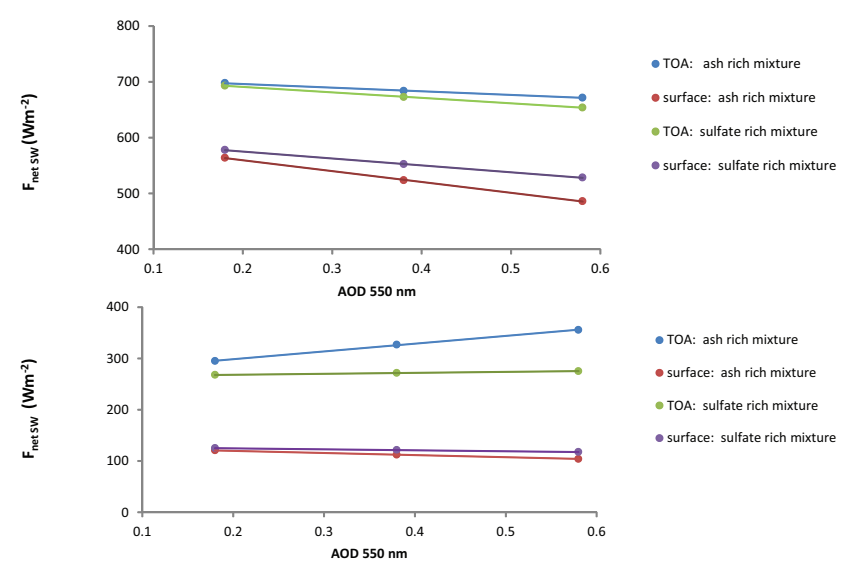

Fig. 7. The relationship between net $\mathrm{SW}$ flux and $\operatorname{AOD}(550 \mathrm{~nm})$ at an AOD range of 0.18-0.58 for two aerosol mixtures at the TOA and surface over seawater (top panel) and snow (bottom panel). SZA is $55^{\circ}$. The $R^{2}$ regressions for all lines are greater than 0.99 .

the net flux at the surface is less for an ash rich plume than for a plume dominated by sulfate. Due to more SW radiation being scattered by a sulfate rich plume, a smaller downward SW flux at the surface is to be expected, producing a lesser net flux at the surface than for an ash rich plume.

Figure 8a illustrates how aerosol composition and AOD affect the distribution of radiation in the atmosphere. Ash rich mixtures lead to more heating in the layer and cooling at the surface, as do larger values of AOD. Compositions rich in ash warm more in the layer and cool more at the surface due to the ability of ash to absorb SW radiation. It is for this reason a volcanic layer containing ash will produce a more positive SW DARFE ${ }_{\text {atm }}$, contributing to warming, and a more neg-

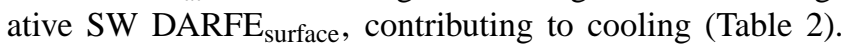


Table 2. Shortwave $(\mathrm{SW})$ and total DARFE for a thin $(\sim 2.5-7 \mathrm{~km})$ plume in $\mathrm{W} \mathrm{m}^{-2} \mathrm{AOD}^{-1}$. DARFE was calculated for a range of AOD between 0.18 and 0.58 .

\begin{tabular}{lcclrrr}
\hline Aerosol mixture & Spectrum & Solar zenith angle & Surface type & DARF TOA & DARF surface & DARF atm \\
\hline ash rich & SW & $55^{\circ}$ & seawater & -65.7 & -194.4 & 128.7 \\
ash rich & SW & $75^{\circ}$ & seawater & -64.0 & -131.9 & 67.9 \\
ash rich & SW & $55^{\circ}$ & snow & 151.0 & -41.4 & 192.4 \\
ash rich & SW & $75^{\circ}$ & snow & 55.3 & -28.2 & 83.5 \\
sulfate rich & SW & $55^{\circ}$ & seawater & -98.1 & -123.8 & 25.7 \\
sulfate rich & SW & $75^{\circ}$ & seawater & -90.6 & -95.3 & 4.7 \\
sulfate rich & SW & $55^{\circ}$ & snow & 18.7 & -18.8 & 37.5 \\
sulfate rich & SW & $75^{\circ}$ & snow & -11.3 & -18.3 & 7.0 \\
ash rich & Total & $55^{\circ}$ & seawater & -46.2 & -155.3 & 109.1 \\
ash rich & Total & $75^{\circ}$ & seawater & -44.5 & -92.8 & 48.3 \\
ash rich & Total & $55^{\circ}$ & snow & 170.5 & -2.3 & 172.8 \\
ash rich & Total & $75^{\circ}$ & snow & 74.7 & 10.9 & 63.8 \\
sulfate rich & Total & $55^{\circ}$ & seawater & -91.8 & -110.1 & 18.4 \\
sulfate rich & Total & $75^{\circ}$ & seawater & -84.3 & -81.7 & -2.6 \\
sulfate rich & Total & $55^{\circ}$ & snow & 25.0 & -5.2 & 30.2 \\
sulfate rich & Total & $75^{\circ}$ & snow & -5.0 & -4.6 & -0.3 \\
\hline
\end{tabular}

However, the extent of warming in the layer and cooling at the surface in SW not only depends on AOD and the relative age of volcanic aerosol, but also on surface albedo and SZA.

The surface albedo of the Arctic region in late winter or early springtime ranges from optically black seawater surfaces to highly reflective snow and ice surfaces. For both compositions of volcanic aerosol, surface and TOA net SW fluxes over snow are less than surface and TOA net fluxes over seawater (Fig. 7). This is because the higher reflectivity of snow causes the upward flux both at the surface and TOA to be greater, leading to smaller net fluxes. The TOA net fluxes for both compositions of volcanic aerosol increase with increasing AOD over snow and decrease with increasing AOD over seawater. This generally leads to positive DARFE TOA $_{\text {over snow and negative DARFE }}$ TOA over seawater for both volcanic compositions (Table 2). This tendency is due to multiple scattering between the surface and the volcanic layer over snow when AOD is increased. The exception to this rule, however, is the case of a sulfate rich plume over seawater at low SZA. In this case, DARFE TOA $_{\text {is }}$ negative because the effect of multiple scattering is drowned out by opposing effects of the composition and SZA.

The effect of multiple scattering over highly reflective surfaces on heating rates can be observed in Fig. 8b. A volcanic layer over snow will absorb more SW radiation due to multiple scattering, warming more in the atmosphere than the same layer over seawater. For a more absorbing aerosol type, such as one comprised mostly of ash, this effect is even more pronounced.

In the Arctic, the changing of seasons brings dramatic shifts of incoming SW radiation. In the summer, the sun never sets, and in winter, the region is in perpetual darkness. Here, DARFE is computed for the highest SZA for a day in mid March $\left(55^{\circ}\right)$ and a lower SZA chosen to represent a middle point between the highest and lowest daily sun angles $\left(75^{\circ}\right)$. A high sun $\left(\mathrm{SZA}=55^{\circ}\right)$ leads to a larger downward SW flux at TOA. Figure 8c illustrates well that when more radiation is entering the system, the heating within the atmosphere is enhanced, especially for a volcanic layer containing larger proportions of absorbing ash. The effect of a low sun $\left(\mathrm{SZA}=75^{\circ}\right)$ on SW DARFE is to decrease the extent of warming or cooling at TOA, at the surface and in the atmosphere (Table 2). Therefore, an eruption occurring very close to the winter solstice would have a negligible $\mathrm{SW}$ radiative effect.

However, both SW and LW radiation must be considered to determine the net radiative impact of a volcanic plume. In some cases, such as during boreal winter, the LW radiation may be more important than SW radiation. From Fig. 1, it is apparent that ash absorbs more SW radiation. Both ash and sulfate absorb and scatter LW radiation, and ash is better overall at attenuating it (Fig 1). This results in net LW TOA fluxes and net surface LW fluxes for sulfate that are more negative than for ash (Fig. 9). The effect of volcanic aerosols on the LW cooling rate profile is shown in Fig. 10. Overall, volcanic aerosols cause cooling in the atmosphere and warming at the surface. The extent of atmospheric cooling or surface warming is dependent upon the aerosol composition and AOD. Compositions rich in ash produce more pronounced cooling in the atmosphere and warming at the surface, because ash is a better absorber of SW radiation and emitter of LW radiation. This effect can also be observed in LW DARFE calculations, which range from 19.5 to $6.3,39.1$ to 13.6 , and -19.6 to $-7.3 \mathrm{~W} \mathrm{~m}^{-2} \mathrm{AOD}^{-1}$ for ash and sulfate rich cases at the TOA, surface and within the atmosphere, respectively. 


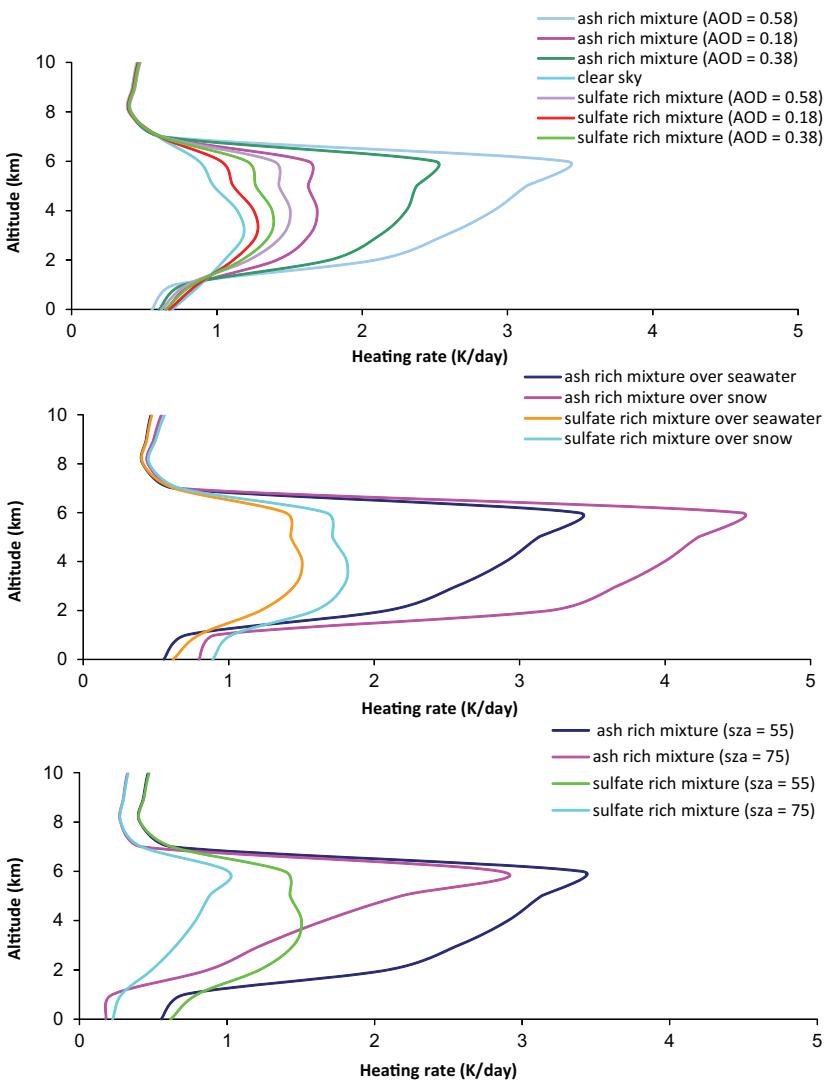

Fig. 8. (a) The effect of aerosol composition and $\operatorname{AOD}(550 \mathrm{~nm})$ of a thin plume $(\sim 2.5-7 \mathrm{~km})$ on $\mathrm{SW}$ heating rate. $\mathrm{SZA}=55^{\circ}$ and surface type is seawater for all cases. (b) The effect of aerosol composition of a thin plume $(\sim 2.5-7 \mathrm{~km})$ and surface type on SW heating rate. $\mathrm{SZA}=55^{\circ}$ and $\mathrm{AOD}(550 \mathrm{~nm})=0.58$ for all cases. (c) The effect of aerosol composition of a thin plume $(\sim 2.5-7 \mathrm{~km})$ and solar zenith angle (SZA) on SW atmospheric heating rate. The $\operatorname{AOD}(550 \mathrm{~nm})=0.58$ and the surface type is seawater for all cases.

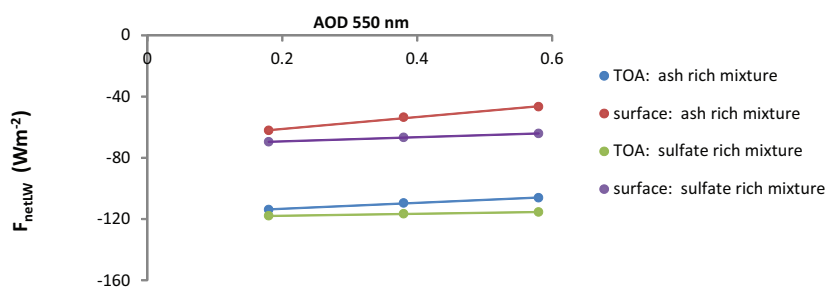

Fig. 9. The relationship between net $\mathrm{LW}$ flux and $\operatorname{AOD}(550 \mathrm{~nm})$ at an AOD range of 0.18-0.58 for two aerosol mixtures at the TOA and surface. The $\mathrm{R}^{2}$ regressions for all lines are greater than 0.99 .

The total radiative forcing associated with this volcanic plume at TOA, at the surface, and in the atmosphere is reported in Table 2. The total DARFE is the sum of SW and LW DARFEs for each case. In most cases, the SW radiation contributes more to the total DARFE. However, there were three instances in which the LW radiation was significant enough to change the sign of the forcing either at the surface or in the atmosphere. These cases were all at a lower zenith angle and either consisted of ash rich plumes over snow or sulfate rich plumes over seawater and snow. The

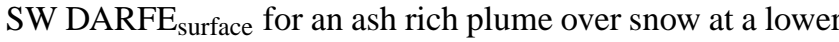
zenith angle produces less cooling than a similarly composed plume under other environmental conditions because of the multiple scattering effect between the aerosol layer and the snow surface and the reduction of solar radiation entering the system due to the lower zenith angle. In this case, LW radiation heats the surface more than the SW radiation cools it, causing a net radiative heating of the surface. A sulfate rich plume under low SZA will tend to warm the atmosphere less than an ash rich plume. This is due to both a reduction in incoming solar radiation and the inability of sulfate to absorb SW radiation. The single scattering albedo $(550 \mathrm{~nm})$ for the ash rich plume is $\sim 0.89$, but it is considerably higher $(\sim 0.98)$ for the sulfate rich plume, indicating there is no appreciable absorption at this wavelength (Fig. 1). For cases of a sulfate rich plume at low SZA over seawater and snow, LW radiation cools the atmosphere more than the $\mathrm{SW}$ radiation warms it, which leads to a net cooling of the atmosphere. These calculations demonstrate the importance of both SW and LW components of the forcing when determining the radiative effects of an aging volcanic plume, especially in the Arctic.

\subsubsection{Examining the role of vertical structure of volcanic aerosol plumes}

The simulated plume for an optically and physically thick eruption column was based on satellite data collected for the entire span of the eruption. A range of AODs from 1 to 3 was selected, and the plume thickness stretched from $3 \mathrm{~km}$ (the volcano summit) to $20 \mathrm{~km}$ altitude. We compared calculated direct aerosol radiative forcing efficiencies and heating rates for an optically thick plume to those produced for the optically thin plume. In this section we demonstrate that, in general, the trends for surface type, SZA, and plume composition discussed above for the thin plume still hold for the thicker plume. However, we also show that the magnitude and, in a few cases, the sign of the forcings and the magnitudes of the heating/cooling rates are very much dependent on plume thickness and AOD.

Net SW fluxes at each AOD for the thick plume over both snow and seawater are shown in Fig. 11. Comparing these results to those for the thin plume in Fig. 8, it immediately becomes apparent that net SW fluxes for the thick plume over seawater, both at the surface and TOA, are considerably less than those for the thin plume at the ranges of AOD chosen for each plume. This is because more of the incoming SW radiation is scattered and absorbed in the thick plume case, resulting in less incoming $\mathrm{SW}$ radiation reaching the surface, and therefore less SW radiation reflected by the surface. Surface net SW fluxes over snow are greater for the thin plume than for the thick one for the same reasoning. However, net 


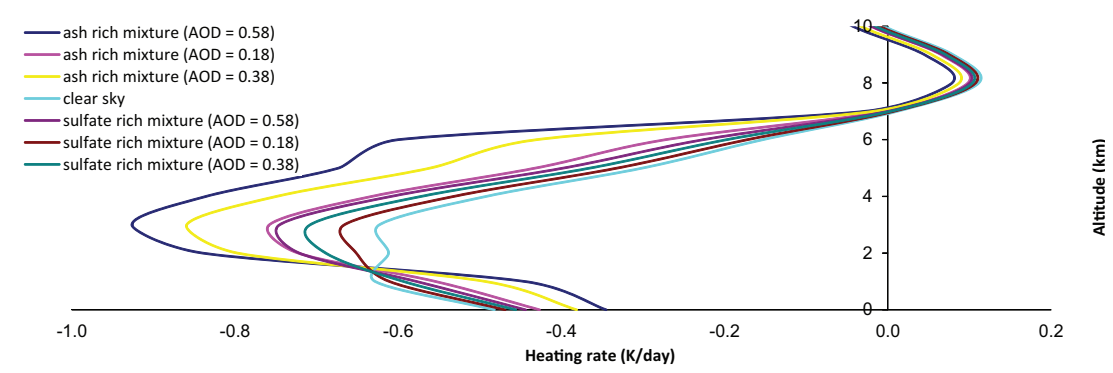

Fig. 10. The effect of aerosol composition and $\operatorname{AOD}(550 \mathrm{~nm})$ of a thin plume $(\sim 2.5-7 \mathrm{~km})$ on $\mathrm{LW}$ cooling rate.

Table 3. Shortwave (SW) and total DARFE for a thick $(\sim 3-20 \mathrm{~km})$ plume in $\mathrm{W} \mathrm{m}^{-2} \mathrm{AOD}^{-1}$. DARFE was calculated for a range of AOD between 1 and 3 .

\begin{tabular}{lcclrrr}
\hline Aerosol mixture & Spectrum & Solar zenith angle & Surface type & DARFE TOA & DARFE surface & DARFE atm \\
\hline ash rich & SW & $55^{\circ}$ & seawater & -20.1 & -100.4 & 80.3 \\
ash rich & SW & $75^{\circ}$ & seawater & -6.7 & -29.9 & 23.2 \\
ash rich & SW & $55^{\circ}$ & snow & 64.2 & -21.3 & 85.5 \\
ash rich & SW & $75^{\circ}$ & snow & 17.7 & -6.4 & 24.1 \\
sulfate rich & SW & $55^{\circ}$ & seawater & -54.2 & -70.1 & 16.0 \\
sulfate rich & SW & $75^{\circ}$ & seawater & -20.6 & -23.4 & 2.9 \\
sulfate rich & SW & $55^{\circ}$ & snow & 11.0 & -12.5 & 23.6 \\
sulfate rich & SW & $75^{\circ}$ & snow & $-2.3 *$ & -4.6 & 5.3 \\
ash rich & Total & $55^{\circ}$ & seawater & -10.3 & -92.4 & 82.1 \\
ash rich & Total & $75^{\circ}$ & seawater & 3.1 & -21.9 & 25.0 \\
ash rich & Total & $55^{\circ}$ & snow & 74.0 & -13.4 & 87.6 \\
ash rich & Total & $75^{\circ}$ & snow & 27.5 & -46 & 25.9 \\
sulfate rich & Total & $55^{\circ}$ & seawater & -46.8 & -64.8 & 18.0 \\
sulfate rich & Total & $75^{\circ}$ & seawater & -13.2 & -18.1 & 4.9 \\
sulfate rich & Total & $55^{\circ}$ & snow & 18.4 & -7.2 & 25.6 \\
sulfate rich & Total & $75^{\circ}$ & snow & 5.1 & 4.3 \\
\hline
\end{tabular}

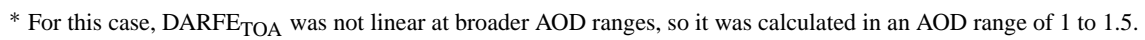

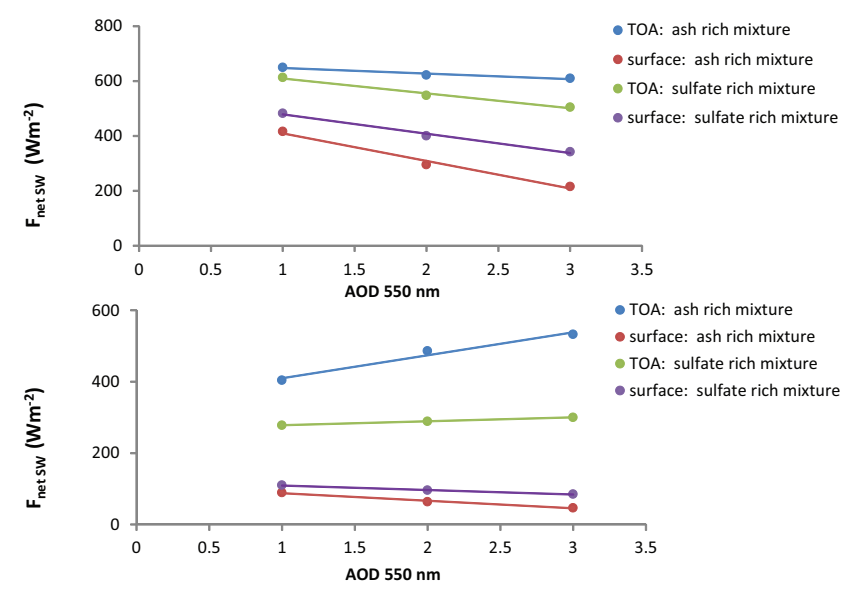

Fig. 11. The relationship between net $S W$ flux and $\operatorname{AOD}(550 \mathrm{~nm})$ at an AOD range of 1-3 for two aerosol mixtures at the TOA and surface over seawater (top panel) and snow (bottom panel). SZA $=55^{\circ}$. The $R^{2}$ regressions for all lines are greater than 0.95 .
SW fluxes are greater for the thick plume at TOA. This is due to less outgoing radiation at TOA because of enhanced multiple scattering occurring between the snow surface and the more opaque plume. Another important comparison in net SW fluxes between plumes is the differences between the two volcanic aerosol compositions at each AOD. For the thicker plume, it seems that plume composition, and therefore plume age, can cause net SW fluxes at the surface and TOA to differ substantially more than for a thinner plume. Calculations of net SW flux must be more sensitive to composition of volcanic aerosol for a thicker plume.

Table 3 presents shortwave DARFEs computed for the thick plume. Like SW DARFE for the thin plume (Table 2), DARFE $_{\text {surface }}$ is negative, indicating cooling, and positive in the atmosphere, indicating warming. However, DARFE values for the thick plume cases are much smaller in magnitude than those for thin plumes. This is a result of the range of AOD over which net flux calculations were performed. The relationship between net flux and AOD can only be approximated as linear when AOD values are small. Because DARFE is computed as the slope of this line, it 

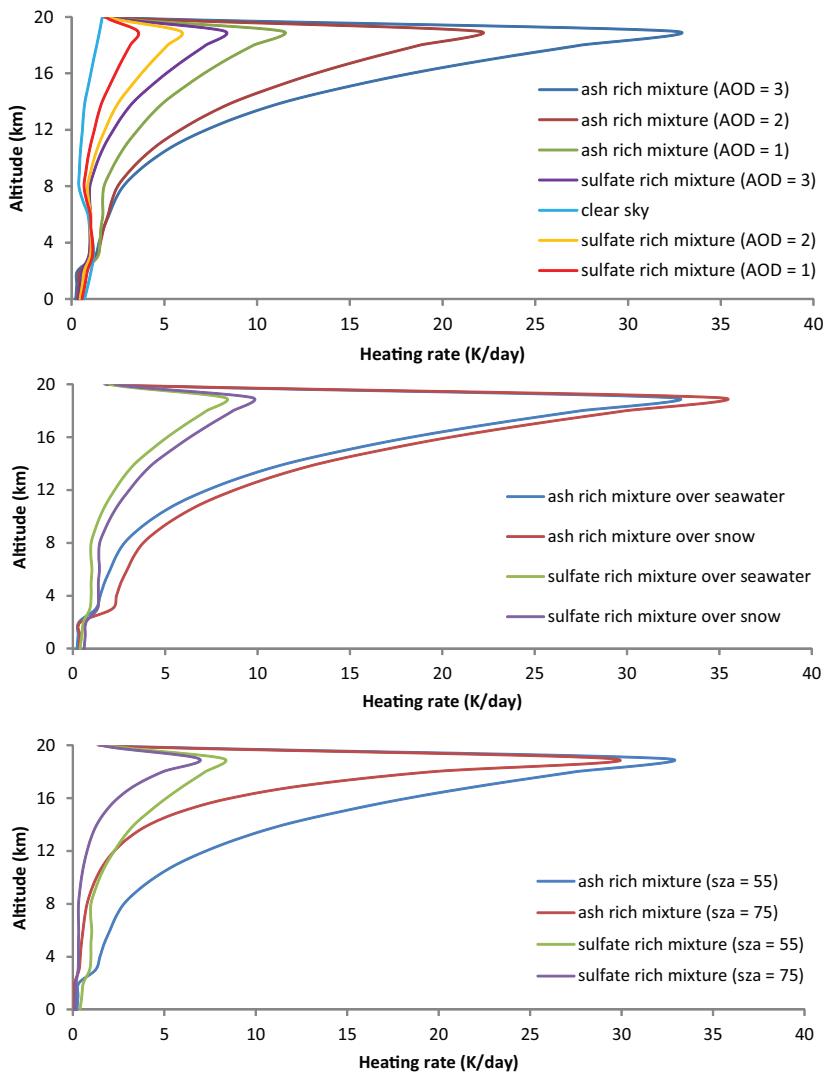

Fig. 12. (a) The effect of aerosol composition and $\operatorname{AOD}(550 \mathrm{~nm})$ of a thick plume $(\sim 3-20 \mathrm{~km})$ on SW heating rate. $\mathrm{SZA}=55^{\circ}$ and surface type is seawater for all cases. (b) The effect of aerosol composition of a thick plume $(\sim 3-20 \mathrm{~km})$ and surface type on SW heating rate. $\mathrm{SZA}=55^{\circ}$ and $\operatorname{AOD}(550 \mathrm{~nm})=3$ for all cases. (c) The effect of aerosol composition of a thick plume $(\sim 3-20 \mathrm{~km})$ and solar zenith angle (SZA) on SW heating rate. The $\operatorname{AOD}(550 \mathrm{~nm})=3$ and the surface type is seawater for all cases.

may depend on the ranges of AOD chosen and must always be reported with this AOD range attached in order to be a meaningful quantity. For the thin plume, the range of AOD used to compute DARFE is narrower and the AOD values are smaller. The net fluxes for the thin plume are more sensitive to changes in AOD at the range chosen, leading to larger DARFE values. However, DARFE is reported in units of $\mathrm{W} \mathrm{m}^{-2} \mathrm{AOD}^{-1}$, and therefore the thick plumes may still produce a larger forcing in $\mathrm{Wm}^{-2}$ depending on the exact values of AOD present.

Shortwave heating rates for the thick plume also exhibit the same general dependences on composition, surface albedo, and SZA as described for the thin plume, with warming in the atmosphere and cooling at the surface (Fig. 12). However, SW heating rates for the thick plume exhibit significant perturbations to clear sky conditions (Fig. 12a), which dwarf those due to the thin volcanic plume discussed above. Heating rates for the thick plume are particularly sensitive

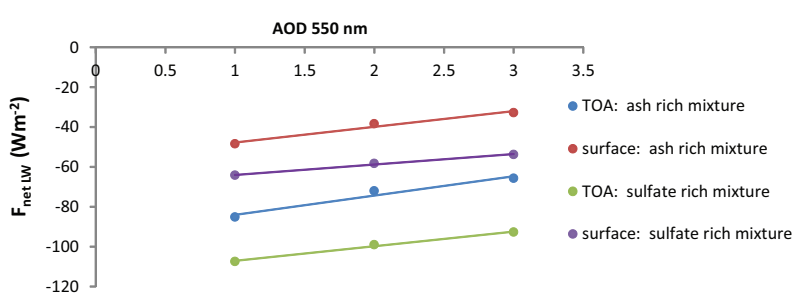

Fig. 13. The relationship between net LW flux and $\operatorname{AOD}(550 \mathrm{~nm})$ at an AOD range of 1-3 for two aerosol mixtures at the TOA and surface. The $R^{2}$ regressions for all lines are greater than 0.96 .

to aerosol composition (Fig. 12a), but have lesser sensitivities to surface reflectivity (Fig. 12b) and SZA (Fig. 12c). This finding emphasizes how strongly plume age controls the way SW radiation is distributed within the aerosol layer and throughout the atmosphere.

The importance of plume age is magnified in the LW part of the spectrum. Given a fixed temperature profile, the LW radiative impacts are entirely dependent on composition and opacity of the aerosol layer, which change as the plume evolves. Net LW fluxes for the thick plume increase with increasing AOD (Fig. 13), similarly to net LW fluxes for the thin plume. However, the differences at TOA and at the surface between the two compositions of volcanic aerosols at each AOD are greater for the thick plume than for the thin plume, indicating that plume age plays a larger role in determining net LW fluxes for a thicker plume. Net LW fluxes also tend to be less negative, both at the surface and TOA, for the thick plume than for the thin plume of the same aerosol composition. A thick layer will emit more LW radiation, producing a net LW flux at the surface which is less negative than for a thin plume. The thick plume will also scatter and absorb more outgoing LW radiation coming from both the surface and within the lower layers of the plume, producing net LW fluxes at TOA that are typically less negative.

The slopes of the lines in Fig. 13 give the LW DARFE for the thick plume cases, which range from 9.8 to 7.4, 8.0 to 5.3 , and 1.8 to $2.1 \mathrm{~W} \mathrm{~m}^{-2} \mathrm{AOD}^{-1}$ for ash and sulfate rich cases at the TOA, surface, and within the atmosphere, respectively. Longwave DARFE for the thick plume is less than those for the thin plume, because net LW fluxes for the thick plume are less sensitive to changes in AOD at the ranges of AOD chosen. Unlike the thin plume cases, DARFE ${ }_{T O A}$ is greater than DARFE surface $_{\text {for both compositions of volcanic }}$ aerosol, leading to positive DARFE $_{\text {atm }}$ for the thick plume. For the thick plume cases, the way in which LW radiation is distributed in the atmosphere is very different. Longwave cooling rates for each aerosol composition and AOD are displayed in Fig. 14. Emission of LW radiation in the upper layers causes cooling in the upper atmosphere, while the surface layers warm due to emission by middle to lower layers and the surface. Longwave emission from the upper and lower layers causes enhanced warming in middle layers. 
Table 4. Studies chosen for comparisons of DARF and heating rates (HR) of Arctic aerosols, along with aerosol types, surface albedo, AOD at 500 or $550 \mathrm{~nm}, \omega_{0}$ (singe scattering albedo) at $550 \mathrm{~nm}$, solar zenith angle (SZA), vertical plume thickness and placement within the atmosphere that were used. Boxes filled with an $\mathrm{X}$ indicate information was not available.

\begin{tabular}{|c|c|c|c|c|c|c|c|}
\hline Study & Aerosol type & Quantity & Surface Albedo & AOD & $\omega_{0}(550 \mathrm{~nm})$ & SZA & Placement (km) \\
\hline Quinn et al. (2007) & haze & SW DARF & 0.92 & 0.12 & 0.94 & daily mean ${ }^{\mathrm{a}}$ & $\mathrm{X}^{\mathrm{b}}$ \\
\hline \multirow[t]{3}{*}{ Stone et al. (2007) } & dust & SW DARF & 0.825 & 0.18 & 0.89 & $62^{\circ}$ & $2-4$ \\
\hline & & SW HR & 0.830 & 0.15 & 0.89 & $75^{\circ}$ & $2-4$ \\
\hline & & LW HR & N/A & 0.4 & 0.89 & N/A & $2-4$ \\
\hline \multirow[t]{2}{*}{ Stone et al. (2008) } & smoke & SW DARF & 0.8 & 0.18 & 0.95 & $50^{\circ}$ & $0.2-2.8$ \\
\hline & & SW HR & 0.2 & 0.28 & 0.95 & $65^{\circ}$ & $0.2-2.8$ \\
\hline Ritter et al. (2005) & haze & LW DARF & N/A & $\mathrm{X}$ & $\mathrm{X}$ & N/A & X \\
\hline \multirow[t]{2}{*}{ This study } & sulfate rich & SW/LW DARF & 0.973 & 0.18 & 0.98 & $55^{\circ}$ & $2.5-7$ \\
\hline & volcanic & SW/LW HR & 0.973 & 0.18 & 0.98 & $75^{\circ}$ & $2.5-7$ \\
\hline \multirow[t]{2}{*}{ This study } & ash rich & SW/LW DARF & 0.973 & 0.18 & 0.89 & $55^{\circ}$ & $2.5-7$ \\
\hline & volcanic & SW/LW HR & 0.973 & 0.18 & 0.89 & $75^{\circ}$ & $2.5-7$ \\
\hline
\end{tabular}

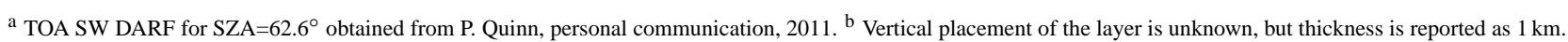

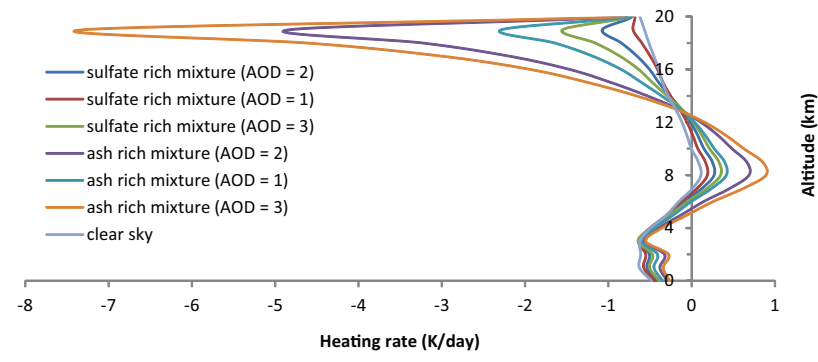

Fig. 14. The effect of aerosol composition and $\operatorname{AOD}(550 \mathrm{~nm})$ of a thick plume $(\sim 3-20 \mathrm{~km})$ on LW cooling rate.

The overall radiative effect of volcanic aerosol in a thick plume is given by the total DARFE, and this is reported for each case in Table 3. For most cases, SW radiation was larger than LW. However, for four of cases under lower sun conditions, LW radiation was large enough to change the sign of the total forcing. At the surface, a net warming was produced for both ash rich and sulfate rich compositions over snow. In these cases, surface SW cooling is reduced due to a reduction of solar energy entering the system and multiple scattering between the snow surface and the aerosol layer. TOA warming was produced for an ash rich plume over seawater and a sulfate rich plume over snow. In these cases, LW warming at TOA was enough to counteract SW cooling. For all of the thick plume cases, net warming in the atmosphere due to SW radiation is enhanced by positive values of LW DARFE.

\subsection{Comparing radiative impacts of major aerosol types in the Arctic}

The radiative effect of aerosol in a given environment depends upon aerosol-specific properties, such as optical characteristics and vertical loading. Volcanic aerosol is unique in that volcanoes are capable of producing huge loadings, forming plumes that can stretch from near surface level to well into the stratosphere. Therefore, it is obvious from the nature of volcanic eruptions that they may produce thicker plumes and may thereby drown out the signal from any other aerosols present. To compare the radiative impact of volcanic aerosol to other aerosol types, Fig. 15 presents direct radiative forcings and heating rates for two volcanic aerosol compositions for the 2 April case from our study, mineral dust (Stone et al., 2007), wildfire smoke (Stone et al., 2008), and haze (Quinn et al., 2007; Ritter et al., 2005). While there are multiple factors which control the regional radiative impact, the most comparable surface albedo, AOD, SZA, and plume thickness for each study were selected in efforts to only assess the effects of differing aerosol compositions and size distributions (Table 4).

Figure 15a compares the surface SW DARF. The ash rich volcanic mixture attenuates more solar radiation per AOD than any other composition, producing the most negative surface forcing. Mineral dust runs a close second to the ash rich mixture, indicating dust must have similar SW extinction coefficients. The ash rich mixture also produces the most warming at TOA and within the atmosphere, which is because the ash rich mixture is the better absorber of SW radiation, as further illustrated by the SW heating rates in Fig. 15b. At the TOA, the DARFs of the sulfate rich mixture and haze are very similar. This may be due to the haze presented in Quinn et al. (2007) consisting of large proportions of sulfate.

The LW DARFs for the two compositions of volcanic aerosol and haze (Ritter et al., 2005), and LW cooling rates for the two volcanic mixtures and dust (Stone et al., 2007) are compared in Fig. 15c and 15d, respectively. The LW forcing for smoke is very small because of small particle sizes (Myhre et al., 2007) and is not shown here. LW forcings of dust and volcanic aerosols are important, although seldom calculated in radiative studies of Arctic aerosols. The ash 

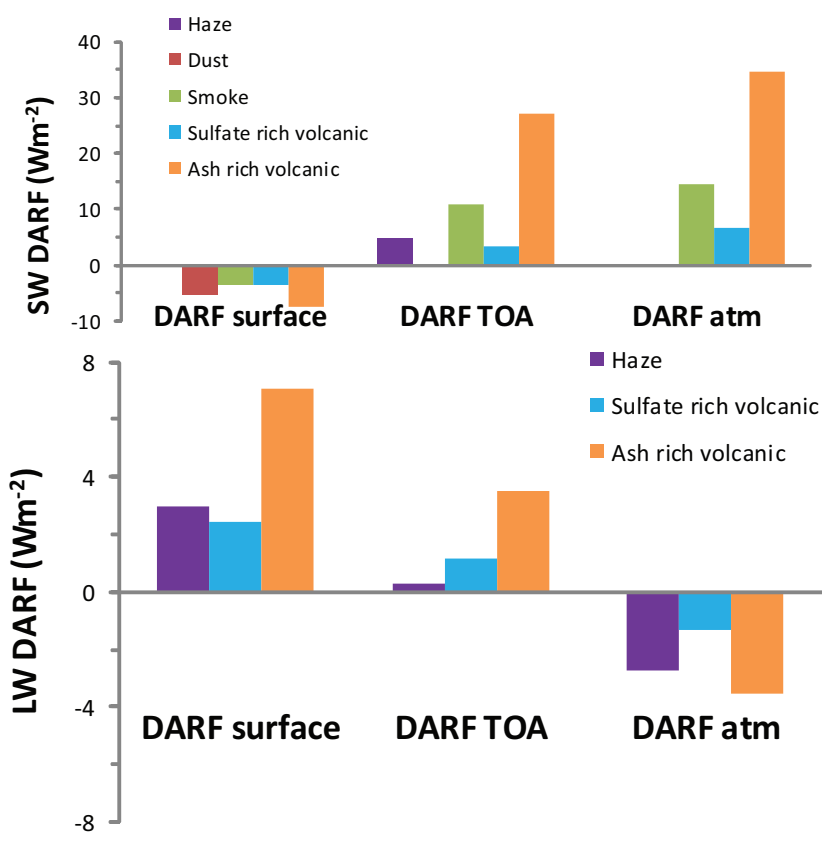

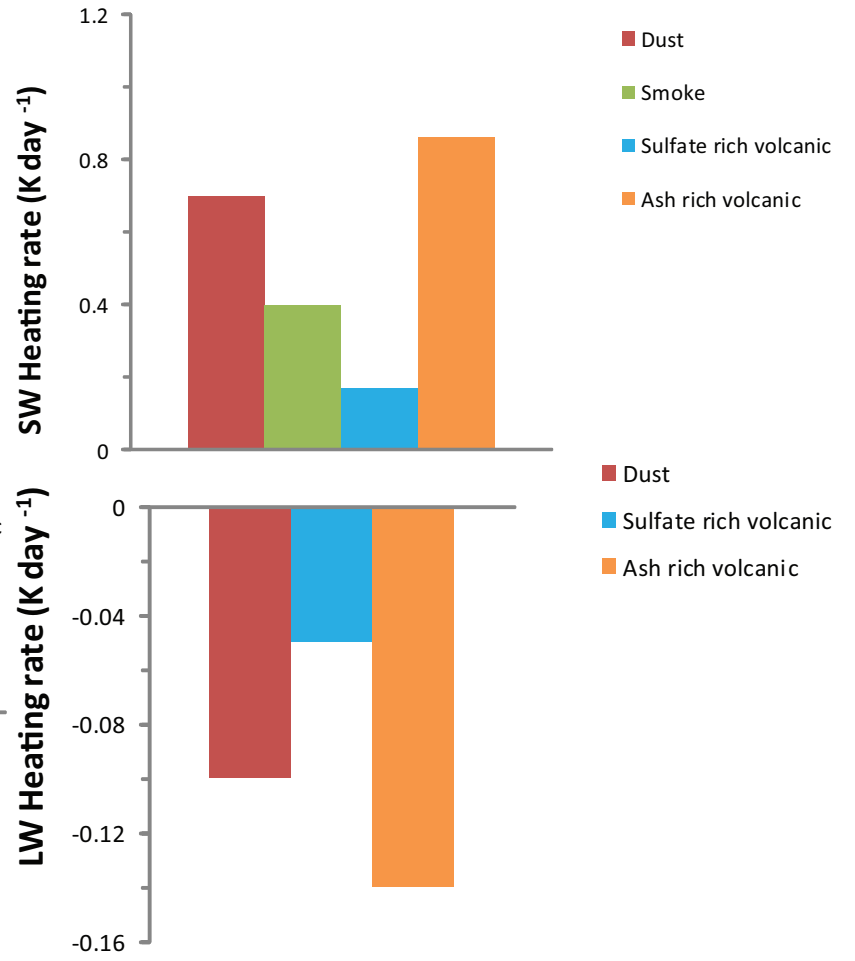

Fig. 15. (a) SW direct radiative forcings (DARFS) and (b) SW heating rates for haze (Quinn et al., 2007), dust (Stone et al., 2007), smoke (Stone et al., 2008), and ash rich and sulfate rich volcanic aerosols (this study). Values of forcing for dust were only available at the surface. (c) LW DARFs for haze (Ritter et al., 2005) and ash rich and sulfate rich volcanic aerosols (this study). (d) LW cooling rates for dust (Stone et al., 2007) and ash rich and sulfate rich volcanic aerosols (this study).

rich mixture seems to dominate the LW radiation as well. Both SW and LW comparisons indicate that even a moderately thin layer of ash rich volcanic aerosol can be a main driver of the aerosol induced radiative impact in the Arctic region. Additionally, the signal due to volcanic aerosol would be expected to be even more powerful given that volcanic eruptions routinely produce aerosol layers with AODs and vertical thicknesses much larger than those of other aerosol types.

\section{Conclusions}

The 2009 eruption of Redoubt volcano provided a source of aerosol to the Arctic environment. The extent to which a given volcanic aerosol layer perturbs the radiation balance depends upon environmental factors, such as surface reflectivity and SZA, and plume specific factors, such as aerosol composition and size distributions, and vertical profile of AOD. We used a satellite integrated approach to investigate the role these factors play in determining the radiative impact of volcanic aerosols in the Arctic. In general, environmental factors can govern both the sign and magnitude of the DARFE and heating/cooling rates. The ability of environmental conditions to change whether an aerosol layer will warm or cool at TOA and the surface is especially sig- nificant when considering the Arctic region, where surfaces vary from ocean to snow, and seasons dramatically shift the amount of incoming solar radiation. The deposition of volcanic ash onto ice and snow surfaces also has strong potential to greatly alter surface reflectivity and thereby cause a perturbation that may last long after the aerosol plume has gone.

Plume specific factors influence the magnitudes of DARFE and heating/cooling rates. The compositions, thicknesses and AODs of volcanic plumes vary greatly and are in many cases difficult factors to constrain. Due to the remote locations of many volcanoes and the dangers involved in making direct measurements, satellites are absolutely necessary to monitor the spatial and temporal development of volcanic plumes. However, eruption specific size distributions and ash to sulfate ratios are challenging to constrain, even with the help of satellite sensors. The development of multiphase models (Dufek and Bergantz, 2007; Neri et al., 2007) to study eruption dynamics may assist in creating better microphysical models for volcanic aerosol. Other plume related simplifications that are often made in radiative transfer modeling which need to be addressed include: the partitioning of volcanic aerosol types at different altitudes and the nonsphericity of ash.

Volcanic eruptions are high intensity events, capable of providing a huge, sporadic aerosol signal compared to other 
Arctic aerosols. However, volcanic eruptions typically have durations shorter than the season long occurrences of Arctic haze or wildfire smoke. Like other Arctic aerosols, volcanic aerosols from high northern latitude eruptions can cover large areas, as in the recent eruption of Eyjafjallajökull in Iceland, which disrupted air travel across Europe. According to the AVO, Alaskan volcanoes have had an average eruption frequency of two per year over the past 40 years, but the appearance of Arctic haze, wildfire smoke, and dust occur only yearly. Therefore, Alaskan volcanic eruptions are on average more frequent than events responsible for the emission of Arctic haze, wildfire smoke, and dust into the Arctic environment. Depending on the time of year, volcanic aerosol may be present along with other aerosol types. Following an eruption in Arctic springtime, dust, haze and volcanic aerosol can contribute to the overall aerosol signal. For eruptions in boreal summer, wildfire smoke will be present along with volcanic aerosols. In boreal winter, these other aerosol types will not be significant contributors, and the LW effects of volcanic aerosols will dominate the regional radiative impacts.

Our results demonstrate a potential for volcanic aerosol to provide a sizeable contribution to the radiative effects and even outshine other types of aerosol when significant proportions of volcanic ash are present, as in young volcanic plumes. Therefore, volcanic aerosol, although sporadically present, can have a significant radiative impact in the region. We recommend that volcanic aerosols be included in future assessments of the Arctic regional radiation budget. This will facilitate efforts to understand the radiative impacts of natural aerosols on the Arctic environment in order to create successful mitigation strategies for warming due to anthropogenic sources.

Acknowledgements. Funding for this work was provided through the NASA Grant No. NNX07AQ26G. Acknowledgment is given to the NOAA Air Resources Laboratory (ARL) for the provision of the HYSPLIT transport and dispersion model and READY website (http://www.arl.noaa.gov/ready.php) used in this publication. The authors are very grateful for personal communications from Janet Schaefer and Michelle Coombs at AVO, and Quinn at NOAA. The authors would like to thank Xin Xi for computing assistance, Hyung-Jin Choi for guidance with CALIPSO data, and Jennifer Telling for a thoughtful review of a draft of this document. The authors also extend their gratitude to three anonymous reviewers for their helpful comments and suggestions, which have greatly improved this manuscript.

Edited by: A. Nenes

\section{References}

Carlile, J., and Nelson, K.: Redoubt Volcano eruption/ ash synopsis - November 2008-July 2009, Federal Aviation Administration, unpublished summary document, 39, 35 pp., 2009.

Carn, S. A., Pallister, J. S., Lara, L., Ewert, J. W., Watt, S., Prata, A. J., Thomas, R. J., and Villarosa, G.: The unexpected awakening of Chaiten Volcano, Chile, Eos, 90, 205-206, 2009.

Clarisse, L., Coheur, P. F., Prata, A. J., Hurtmans, D., Razavi, A., Phulpin, T., Hadji-Lazaro, J., and Clerbaux, C.: Tracking and quantifying volcanic $\mathrm{SO}_{2}$ with IASI, the September 2007 eruption at Jebel at Tair, Atmos. Chem. Phys., 8, 7723-7734, doi:10.5194/acp-8-7723-2008, 2008.

Deshler, T.: A review of global stratospheric aerosol: Measurements, importance, life cycle, and local stratospheric aerosol, Atmos. Res., 90, 223-232, doi:10.1016/j.atmosres.2008.03.016, 2008.

Deshler, T., Hofmann, D. J., Johnson, B. J., and Rozier, W. R.: Balloon-borne measurements of the Pinatubo aerosol size distribution and volatility at Laramie, Wyoming during the summer of 1991, Geophys. Res. Lett., 19, 199-202, 1992.

Deshler, T., Johnson, B. J., and Rozier, W. R.: Balloonborne measurements of Pinatubo aerosol during 1991 and 1992 at 41degrees-n - vertical profiles, size distribution, and volatility, Geophys. Res. Lett., 20, 1435-1438, 1993.

Draxler, R. R. and Rolph, G. D.: HYSPLIT (Hybrid SingleParticle Langrangian Integrated Trajectory model) Model access via NOAA ARL READY website, http://ready.arl.noaa.gov/ HYSPLIT.php, 2011.

Dufek, J. and Bergantz, G. W.: Suspended load and bed-load transport of particle-laden gravity currents: The role of particlebed interaction, Theor. Comp. Fluid Dynam., 21, 119-145, doi:10.1007/s00162-007-0041-6, 2007.

Flanner, M. G., Zender, C. S., Randerson, J. T., and Rasch, P. J.: Present-day climate forcing and response from black carbon in snow, J. Geophys. Res.-Atmos., 112, D11202, doi:10.1029/2006jd008003, 2007.

Hess, M., Koepke, P., and Schult, I.: Optical properties of aerosols and clouds: The software package OPAC, B. Am. Meteorol. Soc., 79, 831-844, 1998.

Jager, H. and Deshler, T.: Lidar backscatter to extinction, mass and area conversions for stratospheric aerosols based on midlatitude balloonborne size distribution measurements, Geophys. Res. Lett., 29, 1929, doi:10.1029/2002g1015609, 2002.

Kearney, C. S., and Watson, I. M.: Correcting satellitebased infrared sulfur dioxide retrievals for the presence of silicate ash, J. Geophys. Res.-Atmos., 114, D22208, doi:10.1029/2008jd011407, 2009.

Klonecki, A., Hess, P., Emmons, L., Smith, L., Orlando, J., and Blake, D.: Seasonal changes in the transport of pollutants into the Arctic troposphere-model study, J. Geophys. Res.-Atmos., 108, 8367, doi:10.1029/2002jd002199, 2003.

Lambert, A., Grainger, R. G., Rodgers, C. D., Taylor, F. W., Mergenthaler, J. L., Kumer, J. B., and Massie, S. T.: Global evolution of the Mt Pinatubo volcanic aerosols observed by the infrared limb-sounding instruments CLAES and ISAMS on the upper atmosphere research satellite, J. Geophys. Res.-Atmos., 102, 1495-1512, 1997.

Lohmann, U., Karcher, B., and Timmreck, C.: Impact of the Mount Pinatubo eruption on cirrus clouds formed by homoge- 
neous freezing in the ECHAM4 $\mathrm{gcm}$, J. Geophys. Res.-Atmos., 108, 4568, doi:10.1029/2002jd003185, 2003.

Martin, R. S., Mather, T. A., Pyle, D. M., Power, M., Tsanev, V. I., Oppenheimer, C., Allen, A. G., Horwell, C. J., and Ward, E. P. W.: Size distributions of fine silicate and other particles in Masaya's volcanic plume, J. Geophys. Res.-Atmos., 114, D09217, doi:10.1029/2008jd011211, 2009.

McClatchey, R. A., Fenn, R. W., Selby, J. E. A., Volz, F. E., and Garing, J. S.: Optical properties of the atmosphere, 3rd ed. AFCRL Environ. Res. Pap., 411, 108, 1972.

Munoz, O., Volten, H., Hovenier, J. W., Veihelmann, B., van der Zande, W. J., Waters, L., and Rose, W. I.: Scattering matrices of volcanic ash particles of Mount St. Helens, redoubt, and mount spurr volcanoes, J. Geophys. Res.-Atmos., 109, D16201, doi:10.1029/2004jd004684, 2004.

Myhre, C. L., Toledano, C., Myhre, G., Stebel, K., Yttri, K. E., Aaltonen, V., Johnsrud, M., Frioud, M., Cachorro, V., De Frutos, A., Lihavainen, H., Campbell, J. R., Chaikovsky, A. P., Shiobara, M., Welton, E. J., and Torseth, K.: Regional aerosol optical properties and radiative impact of the extreme smoke event in the European Arctic in spring 2006, Atmos. Chem. Phys., 7, 58995915, doi:10.5194/acp-7-5899-2007, 2007.

Neri, A., Ongaro, T. E., Menconi, G., Vitturi, M. D., Cavazzoni, C., Erbacci, G., and Baxter, P. J.: 4d simulation of explosive eruption dynamics at Vesuvius, Geophys. Res. Lett., 34, L04309, doi:10.1029/2006g1028597, 2007.

Niemeier, U., Timmreck, C., Graf, H.-F., Kinne, S., Rast, S., and Self, S.: Initial fate of fine ash and sulfur from large volcanic eruptions, Atmos. Chem. Phys., 9, 9043-9057, doi:10.5194/acp9-9043-2009, 2009.

Painter, T. H., Deems, J. S., Belnap, J., Hamlet, A. F., Landry, C. C., and Udall, B.: Response of Colorado River runoff to dust radiative forcing in snow, P. Natl. Acad. Sci. USA, 107, 1712517130, doi:10.1073/pnas.0913139107, 2010.

Pollack, J. B., Toon, O. B., and Khare, B. N.: Optical properties of terrestial rocks and glasses, Icarus, 19, 372-389, 1973.

Prata, A. J., Carn, S. A., Stohl, A., and Kerkmann, J.: Long range transport and fate of a stratospheric volcanic cloud from Soufriere Hills Volcano, Montserrat, Atmos. Chem. Phys., 7, 5093-5103, doi:10.5194/acp-7-5093-2007, 2007.

Pueschel, R. F., Russell, P. B., Allen, D. A., Ferry, G. V., Snetsinger, K. G., Livingston, J. M., and Verma, S.: Physical and opticalproperties of the Pinatubo volcanic aerosol - aircraft observations with impactors and a sun-tracking photometer, J. Geophys. Res.-Atmos., 99, 12915-12922, 1994.

Quinn, P. K., Shaw, G., Andrews, E., Dutton, E. G., RuohoAirola, T., and Gong, S. L.: Arctic haze: Current trends and knowledge gaps, Tellus B, 59, 99-114, doi:10.1111/j.16000889.2006.00238.x, 2007.

Quinn, P. K., Bates, T. S., Baum, E., Doubleday, N., Fiore, A. M., Flanner, M., Fridlind, A., Garrett, T. J., Koch, D., Menon, S., Shindell, D., Stohl, A., and Warren, S. G.: Short-lived pollutants in the Arctic: Their climate impact and possible mitigation strategies, Atmos. Chem. Phys., 8, 1723-1735, doi:10.5194/acp8-1723-2008, 2008.

Ramachandran, S., Ramaswamy, V., Stenchikov, G. L., and Robock, A.: Radiative impact of the Mount Pinatubo volcanic eruption: Lower stratospheric response, J. Geophys. Res.Atmos., 105, 24409-24429, 2000.
Remer, L. A., Kaufman, Y. J., Tanre, D., Mattoo, S., Chu, D. A., Martins, J. V., Li, R. R., Ichoku, C., Levy, R. C., Kleidman, R. G., Eck, T. F., Vermote, E., and Holben, B. N.: The MODIS aerosol algorithm, products and validation. J. Atmos. Sci., 62, 947-973, 2005.

Ricchiazzi, P., Yang, S. R., Gautier, C., and Sowle, D.: Sbdart: A research and teaching software tool for plane-parallell radiative transfer in the earth's atmosphere, B. Am. Meteorol. Soc., 79, 2101-2114, 1998.

Riley, C. M., Rose, W. I., and Bluth, G. J. S.: Quantitative shape measurements of distal volcanic ash, J. Geophys. Res.-Sol. Earth, 108, 2504, doi:10.1029/2001jb000818, 2003.

Ritter, C., Notholt, J., Fischer, J., and Rathke, C.: Direct thermal radiative forcing of tropospheric aerosol in the arctic measured by ground based infrared spectrometry, Geophys. Res. Lett., 32, L23816, doi:10.1029/2005g1024331, 2005.

Robock, A.: Volcanic eruptions and climate, Rev. Geophys., 38, 191-219, 2000.

Rolph, G. D.: Real-time environmental applications and display system (ready): Website http://ready.arl.noaa.gov, 2011.

Rose, W. I. and Durant, A. J.: Fine ash content of explosive eruptions, J. Volcanol. Geoth. Res., 186, 32-39, doi:10.1016/j.jvolgeores.2009.01.010, 2009.

Rose, W. I., Bluth, G. J. S., and Watson, I. M.: Ice in volcanic clouds: When and where?, Proceedings of the 2nd International Conference on Volcanic Ash and Aviation Safety, OFCM Washington, DC, USA, 2004.

Russell, P. B., Livingston, J. M., Pueschel, R. F., Bauman, J. J., Pollack J. B., Brooks, S. L., Hamill, P., Thomason, L. W., Stowe, L. L., Deshler, T., Dutton E. G., and Bergstrom, R. W.: Global to microscale evolution of the Pinatubo volcanic aerosol, derived from diverse measurements and analyses, J. Geophys. Res., 101, 18745-18763, 1996.

Scott, W. E. and McGimsey, R. G.: Character, mass, distribution, and origin of tephra-fall deposits of the 1989-1990 eruption of redoubt volcano, south-central Alaska, J. Volcanol. Geoth. Res., 62, 251-272, 1994.

Shaw, G. E. and Stamnes, K.: Arctic haze: Perturbation of the polar radiation budget, Ann. NY Acad. Sci., 338, 533-539, 1980.

Sokolik, I. N., Curry, J. A., and Radionov, V.: Interactions of Arctic aerosols with land-cover and land-use changes in Northern Eurasia and their role in the Arctic climate system. In Arctic land-cover and land-use in a changing climate: Focus on Eurasia, edited by: Gutman G. and Reissell, A. Springer, 2011.

Spinetti, C., Corradini, S., Carboni, E., Thomas, G., Grainger, R., and Buongiorno, M. F.: Mt. Etna volcanic aerosol and ash retrievals using MERIS and AATSR data, Proceedings of the 2nd MERIS/(A)ATSR Workshop, Frascati, Italy, 2008.

Stenchikov, G. L., Kirchner, I., Robock, A., Graf, H. F., Antuna, J. C., Grainger, R. G., Lambert, A., and Thomason, L.: Radiative forcing from the 1991 Mount Pinatubo volcanic eruption, J. Geophys. Res.-Atmos., 103, 13837-13857, 1998.

Stier, P., Feichter, J., Kinne, S., Kloster, S., Vignati, E., Wilson, J., Ganzeveld, L., Tegen, I., Werner, M., Balkanski, Y., Schulz, M., Boucher, O., Minikin, A., and Petzold, A.: The aerosolclimate model ECHAM5-HAM, Atmos. Chem. Phys., 5, 11251156, doi:10.5194/acp-5-1125-2005, 2005.

Stohl, A.: Characteristics of atmospheric transport into the Arctic troposphere, J. Geophys. Res.-Atmos., 111, D11306, 
doi:10.1029/2005jd006888, 2006.

Stone, R. S., Herber, A., Vitale, V., Mazzola, M., Lupi, A., Schnell, R. C., Dutton, E. G., Liu, P. S. K., Li, S. M., Dethloff, K., Lampert, A., Ritter, C., Stock, M., Neuber, R., and Maturilli, M.: A three-dimensional characterization of arctic aerosols from airborne sun photometer observations: Pamarcmip, April 2009, J. Geophys. Res.-Atmos., 115, D13203, doi:10.1029/2009jd013605, 2009.

Stone, R. S., Anderson, G. P., Andrews, E., Dutton, E. G., and Shettle, E. P.: Incursions and radiative impact of Asian dust in northern Alaska, Geophys. Res. Lett., 34, L14815, 10.1029/2007gl029878, 2007.

Stone, R. S., Anderson, G. P., Shettle, E. P., Andrews, E., Loukachine, K., Dutton, E. G., Schaaf, C., and Roman, M. O.: Radiative impact of boreal smoke in the arctic: Observed and modeled, J. Geophys. Res.-Atmos., 113, D14s16, doi:10.1029/2007jd009657, 2008.

Textor, C., Graf, H. F., Herzog, M., Oberhuber, J. M., Rose, W. I., and Ernst, G. G. J.: Volcanic particle aggregation in explosive eruption columns, Part I: Parameterization of the microphysics of hydrometeors and ash, J. Volcanol. Geoth. Res., 150, 359-377, doi:10.1016/j.jvolgeores.2005.09.007, 2006.

Thomas, H. E., Watson, I. M., Kearney, C., Carn, S. A., and Murray, S. J.: A multi-sensor comparison of sulphur dioxide emissions from the 2005 eruption of Sierra Negra Volcano, Galapagos Islands, Remote Sens. Environ., 113, 1331-1342, doi:10.1016/j.rse.2009.02.019, 2009.
Thomason, L. W. and Pitts, M. C.: CALIPSO observations of volcanic aerosol in the stratosphere, Proc. SPIE, 7153, doi:10.1117/12.804090, 2008.

Torres, O., Tanskanen, A., Veihelmann, B., Ahn, C., Braak, R., Bhartia, P. K., Veefkind, P., and Levelt, P.: Aerosols and surface UV products from ozone monitoring instrument observations: An overview, J. Geophys. Res.-Atmos., 112, D24S47, doi:10.1029/2007jd008809, 2007.

Viollier, M.: Teledetection des concentrations de seston et pigments chlorophylliens contenus dans l'Ocean, These de Doctorat d'Etat, 503, 1980.

Williams, E. R., and McNutt, S. R.: Total water contents in volcanic eruption clouds and implications for electrification and lightning, in: Research signpost, recent progress in lightning physics, edited by: Pontikis, C., Research Signpost, Kerala, India, 81-93, 2005.

Wiscombe, W. J. and Warren, S. G.: A model for the spectral albedo of snow. I: pure snow, J. Atmos. Sci., 37, 2712-2733, 1980.

Yuan, T., Remer, L. A., and Yu, H.: Microphysical, macrophysical and radiative signatures of volcanic aerosols in trade wind cumulus observed by the A-Train, Atmos. Chem. Phys., 11, 71197132, doi:10.5194/acp-11-7119-2011, 2011.

Yue, G. K., Poole, L. R., Wang, P. H., and Chiou, E. W.: Stratospheric aerosol acidity, density, and refractive-index deduced from SAGE-II and NMC temperature data, J. Geophys. Res.Atmos., 99, 3727-3738, 1994. 